\title{
Multiple myeloma etiology and treatment
}

\author{
Humaira Sadaf', Hanna Hong', Mohsin Maqbool', Kylin Emhoff', Jianhong Lin², Shan Yan ${ }^{3}$, Faiz Anwer ${ }^{4}$, \\ Jianjun Zhao ${ }^{2}$ \\ 'Department of Pathology and Laboratory Medicine, University of Texas McGovern Medical School, Houston, TX 77030, USA. \\ 2Department of Cancer Biology, Lerner Research Institute, Cleveland Clinic, Cleveland, OH 44195, USA. \\ ${ }^{3}$ Department of Biological Sciences, College of Liberal Arts \& Sciences, University of North Carolina at Charlotte, Charlotte, NC \\ 28223, USA. \\ ${ }^{4}$ Department of Hematology and Medical Oncology, Taussig Cancer Institute, Cleveland Clinic, Cleveland, OH 44195, USA.
}

Correspondence to: Jianjun Zhao, Department of Cancer Biology, Lerner Research Institute, Cleveland Clinic, 9500 Euclid Avenue, NB40, Cleveland, OH 44195, USA. E-mail: zhaoj4@ccf.org

How to cite this article: Sadaf H, Hong H, Maqbool M, Emhoff K, Lin J, Yan S, Anwer F, Zhao J. Multiple myeloma etiology and treatment. J Trans/ Genet Genom 2022;6:63-83. https://dx.doi.org/10.20517/jtgg.2021.36

Received: 22 July 2021 First Decision: 26 Oct 2021 Revised: 19 Nov 2021 Accepted: 21 Dec 2021 Published: 20 Jan 2022

Academic Editor: Susan L. Slager Copy Editor: Yue-Yue Zhang Production Editor: Yue-Yue Zhang

\begin{abstract}
Genomic aberrations comprise hallmarks of multiple myeloma (MM), a plasma cell malignancy with an overall poor prognosis. MM is heterogeneous and has different molecularly-defined subtypes according to varying clinical and pathological features. Hyperdiploidy or non-hyperdiploidy has usually been identified as early initiating genetic events that can be followed by secondary aberrations, including copy number changes, secondary translocations, and different epigenetic modifications, which cause immortalization of plasma cell and disease progression. Even though recent advances in drug discovery have offered new perspectives of treatment, MM remains incurable. However, understanding the molecular complexity of MM would allow patients to get precision treatment. Our review focuses on current evidence in myeloma biology with special attention to genomic and molecular variations.
\end{abstract}

Keywords: Multiple myeloma, cancer genetics, targeted therapy, clinical trial

\section{INTRODUCTION}

Multiple myeloma (MM) is an incurable neoplasm of terminally differentiated B lymphocytes called plasma cells, which occurs in bone marrow and secretes immunoglobulin ${ }^{[1]}$. MM mainly affects elderly people, and the median diagnosed age is $69^{[2]}$. It has a poor prognosis, and the 5 -year overall survival rate is $48.5 \%{ }^{[1]}$. 
Genomic aberrations are central to the development and progression of multiple myeloma ${ }^{[3]}$. Genomic instability affects all levels of the genome and leads to two types of aberrations: large-scale and small-scale ${ }^{[3]}$. Large-scale aberrations include insertions, deletions, translocations, and inversions ${ }^{[4]}$. These aberrations can be revealed in tumor cells during the metaphase of the mitotic cycle using traditional Giemsa banding and spectral karyotyping ${ }^{[5]}$. Similarly, fluorescence in situ hybridization and other molecular cytogenetic approaches can identify large-scale aberrations in interphase cells ${ }^{[6]}$. Small-scale aberrations include small insertions and deletions (indels), loss of heterozygosity, copy number changes, and base substitution mutations ${ }^{[3]}$. Next-generation sequencing (NGS) is a collection of methods that can identify small-scale aberrations and includes whole-genome sequencing and protein-encoding exome sequencing (WES $)^{[7,8]}$. Recently, transcriptome-wide sequencing has allowed for the identification of subtypes stratified by cells of origin and genomic/epigenetic alterations ${ }^{[0]}$. To this end, analysis of a 70 -gene prognostic signature developed by the University of Arkansas for Medical Sciences has been used and validated to stratify risk for relapse and survival ${ }^{[10]}$. Furthermore, transcriptome sequencing-based stratification can predict response to MM therapy, as shown with MCL1-M co-expression and bortezomib response $\mathrm{e}^{[11]}$.

In the cytogenetic approach, MM initiation and progression involve primary and secondary events. Primary events responsible for plasma cell immortalization are further categorized into two subtypes: hyperdiploid (HRD) and non-hyperdiploid (non-HRD). HRD subtype is correlated with trisomies of the odd-numbered chromosomes $(3,5,7,9,11,15,19$, and 21). Non-HRD subtype involves balanced chromosomal translocations, with more than $90 \%$ of non-HRD cases affecting the transcriptionally active IgH locus on 14q32. The primary translocations $\mathrm{t}(4 ; 14), \mathrm{t}(6 ; 14), \mathrm{t}(11 ; 14), \mathrm{t}(14 ; 16)$, and $\mathrm{t}(14 ; 20)$ cause over-expression of oncogenes MMSET/FGFR3, CCND3, CCND1, MAF, and MAFB ${ }^{[12,13]}$. These primary translocations can be found in about $50 \%$ monoclonal gammopathy of undetermined significance (MGUS) patients as an early event, which takes place in the lymphoid germinal center during physiological class-switch recombination and somatic hypermutation ${ }^{[14]}$. Either directly or indirectly, HRD and non-HRD events can cause dysregulation of the G1/S cell cycle transition point through the over-expression of cyclin $\mathrm{D}$ genes, which is a key to an early molecular abnormality in myeloma ${ }^{[15]}$. The secondary events involved in myeloma progression occur later in the disease and include secondary translocations: $t(8 ; 14)$ linked with MYC overexpression, loss of heterozygosity, copy number variations (CNV), acquired mutations, and epigenetic modifications $^{[1,14]}$.

One of the pivotal aspects of MM is the recognizable clinical phase linked to each step of MM development. MGUS and smoldering multiple myeloma (SMM) are both early premalignant phases. MGUS is asymptomatic and is characterized by a $<10 \%$ plasma cell count in the bone marrow and a progression rate of $1 \%$ per year to MM. SMM follows MGUS; it is also an asymptomatic phase with $>10 \%$ intramedullary clonal plasma cells and 10\% per year progression risk to MM. Thirdly, overt MM presents clinical features of hypercalcemia, renal dysfunction, anemia, and bone disease (the acronym CRAB). Lastly, plasma cell leukemia (PCL) is characterized by extramedullary plasma cell clones and rapid progression to death. Hence, the disease continuity between MGUS, SMM, and MM involves genomic hierarchy, including germline events that increase predisposition to MM, followed by early initiating events, and later gaining of genomic aberrations that ultimately trigger disease progression and treatment resistance ${ }^{[15]}$.

\section{GENETIC PREDISPOSITION}

The inherited susceptibility to MM is well established, with an estimated heritability of about $15 \%$ and $17 \%$ for MGUS and MM respectively ${ }^{[16]}$. In 2010, a Swedish study comprising 13,896 MM patients revealed firstdegree relatives of MM patients having a higher relative risk $(R R)$ to develop MM $(R R=2.1)$, MGUS $(R R=$ 2.1 , acute lymphoblastic leukemia $(R R=2.1)$ and, to a lesser extent, solid tumors $(R R=1.1)^{[17]}$. There is a 
4.25-fold risk of MM in first-degree relatives (95\%CI: 1.81-8.41) that was observed in the 1961-2003 Swedish national cancer registry data ${ }^{[18]}$. Similarly, among the first-degree relatives observed in Minnesota and Mayo Clinic cohorts exhibited the increased risk of MGUS ( $R R=3.3$; 95\%CI: 2.1-4.8) and MM (RR $=2.0 ; 95 \% \mathrm{CI}$ : 1.4-2.8 ${ }^{[19]}$. While the familial clustering of MM indicates a genetic predisposition to the disease, only recently (2012) has GWAS identified single-nucleotide polymorphisms associated with MM risk ${ }^{[20]}$. In addition to identifying multiple risk loci, GWAS has provided innovative insights into genetic-related risk $^{[20]}$. Inherited variations at loci $2 \mathrm{p} 23.3,3 \mathrm{p} 22.1$, and $7 \mathrm{p} 15.3$ are associated with a genetic predisposition to MGUS and involves gene pairs 2p: DNMT3A and DTNB, 3p: ULK4 and TRAK1, and 7p: DNAH11 and $C D C A 7 L^{[21,22]}$. Chubb et al. ${ }^{[23]}$ verified that the seven common variant loci $2 \mathrm{p} 23.3,3 \mathrm{p} 22.1,3 \mathrm{q} 26.2,6 \mathrm{p} 21.33$, 7p15.3, 17p11.2, and 22q13.1 may account for 13\% of the familial risk of MM. Further studies have confirmed more candidate loci summarized in Table 1. Additionally, rare variants such as $L S D 1 / K D M 1 A$, KIF18A, USP45, ARDID1A, CDKN2A, and DIS3 may be contributed to missing heritability ${ }^{[16]}$. The reliable identification of these susceptible risk variants would be an important advancement in the early detection of MM. Furthermore, it could postulate potential personalized treatments or gene knockdown to limit progression to $\mathrm{MM}$ in the future.

The African American (AA) population has a higher prevalence of MGUS and MM than Caucasian Americans (CA) of European ancestry ${ }^{[30,31]}$. A study by Costa et al.$^{[32]}$ reported a 2.24-fold higher incidence of MM in AA men compared to CA men. Also, MM occurs in the AA population at an early age of 65.8 compared to age 69.8 in the CA population ${ }^{[33]}$. When considering polygenic risk scores (PRS), people of African ancestry in the top $10 \%$ PRS had a 1.82-fold (95\%CI: 1.56-2.11) increased risk for MM compared to those with an average risk ${ }^{[34]}$. Although the confounding factors of healthcare inequalities, lifestyle, and environmental factors are significant, racial genetics is crucial in the etiology of MM in the AA population $^{[20]}$.

A study involving GWAS analysis revealed a stronger association between the 7p15.3 (rs4487645) locus and $\mathrm{MM}$ in $\mathrm{AA}^{[35]}$. The expression quantitative trait locus analysis on the biological function of the $7 \mathrm{p} 15.3$ (rs4487645) risk locus showed that the C risk allele is linked to elevated CDCA7L (cell division cycleassociated 7 like $)^{[36]}$. The elevated CDCA7L attributes to the emergence of an IRF4 binding site on the 7 p15.3 enhancer ${ }^{[37]}$, hence, connecting the germline risk of MM to a genetic pathway IRF4-MYC.

Similarly, an NGS study about acquired somatic mutations in MMmyeloma has underlined new insights into racial differences between $\mathrm{AA}$ and CA patients. It demonstrated higher mutation frequency in genes ABI3BP, ANKRD26, AUTS2, BCL7A, BRWD3, DDX17, GRM7, IRF4, MYH13, PARP4, PLD1, PTCHD3, $R P L 10, R Y R 1, S P E F 2, S T X B P 4$, and TP53 among AA than in CA myeloma patients ${ }^{[3]}$. Besides, myeloma $\mathrm{MM}$-associated translocations $\mathrm{t}(11 ; 14), \mathrm{t}(14 ; 16)$, and $\mathrm{t}(14 ; 20)$ also play a critical role in racial AA $v s$. CA disparity ${ }^{[38]}$.

\section{TRANSLOCATIONS IN MYELOMA}

\section{Translocation (4;14) (p16.3;q32.3)}

The translocaton $\mathrm{t}(4 ; 14)$ is seen in $15 \%$ of MM cases and has a poor prognosis ${ }^{[39,40]}$. This translocation results in the over-expression of two genes: FGFR3 (70\% of cases) and MMSET (all cases) ${ }^{[41,42]}$. FGFR3 upregulation results in the ectopic expression of the FGFR3 tyrosine kinase receptor types ${ }^{[43]}$. MMSET is a methyltransferase protein. Its up-regulation leads to enhanced methylation of histone $\mathrm{H} 3 \mathrm{~K} 36$, which modulates the expression of several genes. MMSET also regulates the methylation of histone $\mathrm{H} 4 \mathrm{~K} 20$, subsequently affecting the recruitment of tumor protein p53binding protein 1 (TP53BP1) at the site of DNA damage ${ }^{[44]}$. Both MMSET and FGFR3 over-expression up-regulate CCND2 and in some instances CCND1 
Table 1. Susceptible loci for multiple myeloma

\begin{tabular}{|c|c|c|}
\hline Study & Locus & Candidate gene \\
\hline $\begin{array}{l}\text { Broderick et al al[21] } 2012 \\
\text { Martino et al. }{ }^{[24]}, 2012\end{array}$ & $\begin{array}{l}2 p 23.3 \\
3 p 22 \\
7 p 15.3\end{array}$ & $\begin{array}{l}\text { DNMT3A } \\
\text { ULK4 } \\
\text { CDCA7L }\end{array}$ \\
\hline Koura et al. ${ }^{[22]}, 2013$ & $\begin{array}{l}2 p 23.3 \\
3 p 22.1 \\
7 p 15.3 \\
8 q 24\end{array}$ & $\begin{array}{l}\text { DNMT3A } \\
\text { ULK4 } \\
\text { CDCA7L } \\
\text { MYC }\end{array}$ \\
\hline Chubb et al. ${ }^{[23]}, 2013$ & $\begin{array}{l}3 q 26.2 \\
6 p 21.3 \\
17 p 11.2 \\
22 q 13.1\end{array}$ & $\begin{array}{l}\text { TERC } \\
\text { PSORS1C2 } \\
\text { TNFRSF13B } \\
\text { APOBEC }\end{array}$ \\
\hline Weinhold et al. ${ }^{[25]}, 2014$ & $\begin{array}{l}2 p 23.3 \\
3 p 22.1 \\
3 q 26.2 \\
6 p 21.3 \\
7 p 15.3 \\
17 p 11.2 \\
22 q 13.1\end{array}$ & $\begin{array}{l}\text { DNMT3A } \\
\text { ULK4 } \\
\text { TERC } \\
\text { PSORS1C2 } \\
\text { CDCA7L } \\
\text { TNFRSF13B } \\
\text { APOBEC }\end{array}$ \\
\hline Ziv et al. ${ }^{[26]}, 2015$ & $16 \mathrm{p} 13$ & FOPNL \\
\hline Mitchell et al. ${ }^{[27]}, 2016$ & $\begin{array}{l}5 q 15 \\
6 p 22.3 \\
6 q 21.3 \\
7 q 36.1 \\
8 q 24.1 \\
9 p 21.3 \\
16 q 23.1 \\
20 q 13.1\end{array}$ & $\begin{array}{l}\text { ELL2 } \\
\text { JARID2 } \\
\text { ATG5 } \\
\text { SMARCD3 } \\
\text { CCAT1 } \\
\text { MTAP } \\
\text { RFWD3 } \\
\text { PREX1 }\end{array}$ \\
\hline Went et al. ${ }^{[28]}, 2018$ & $\begin{array}{l}2 q 31.1 \\
5 q 23.2 \\
7 q 22.3 \\
7 q 31.33 \\
16 p 11.2 \\
19 p 13.11 \\
22 q 13.1\end{array}$ & $\begin{array}{l}\text { SP3 } \\
\text { CEP120 } \\
\text { CCDC71L } \\
\text { POT1 } \\
\text { PRR14 } \\
\text { KLF2 } \\
\text { CBX7 }\end{array}$ \\
\hline Duran-Lozanzo et al. ${ }^{[29]}, 2021$ & $13 q 13.3$ & SOHLH2 \\
\hline
\end{tabular}

via unknown mechanisms ${ }^{[12]}$. Notwithstanding $\mathrm{t}(4 ; 14)$ being associated with a poor prognosis of MM, treatment of MM with bortezomib, a proteasome inhibitor (PI), results in an increased survival rate in these patients $^{[45]}$.

\section{Translocation $(6 ; 14)(p 21 ; q 32)$}

The translocation $\mathrm{t}(6 ; 14)$ is rare and is present in only $2 \%$ of MM patients $\mathrm{s}^{[1]}$. It has a neutral prognosis. This translocation causes the juxtaposition of $C C N D 3$ to the IGH enhancers, thus directly up-regulating $C C N D 3$ $\operatorname{expression}^{[46]}$.

\section{Translocation $(11 ; 14)(\mathrm{q} 13 ; 32)$}

The translocation $\mathrm{t}(11 ; 14)$ is the most frequent translocation present in MM (15\%-20\% patients ${ }^{[1]}$. It has a neutral prognosis, although $t(11 ; 14)$ patients show significant heterogeneity and may present as $\mathrm{PCL}^{[14]}$. This translocation up-regulates a cyclin D gene in the CCND1 form. Gene studies demonstrated that the overexpression of CCND1 and CCND3 results in the deregulation of common downstream transcriptional events $^{[47]}$. The central role of cyclin D gene deregulation in MM provided insight into research on cyclin D inhibitors in vitro. Human trials on cyclin D inhibition therapy for MM are also under consideration ${ }^{[48]}$. 


\section{Translocation $\mathrm{t}(14 ; 16)(\mathrm{q} 32.3 ; \mathrm{q} 23)$}

The translocation $\mathrm{t}(14 ; 16)$ shows up in $5 \%-10 \% \mathrm{MM}_{\text {patients }}{ }^{[1]}$. This translocation is associated with a poor prognosis; however, a large retrospective analysis of 1003 patients with $t(14 ; 16)$ revoked its prognostic significance ${ }^{[49]}$. The $t(14 ; 16)$ gives rise to over-expression of the $M A F$ gene splice variant $c-M A F$, which is a transcription factor that up-regulates a couple of genes, including $C C N D 2$, by directly binding to its promoter $^{[50]}$. MAF up-regulates the expression of $A P O B E C 3 A$ and $A P O B E C 3 B$, two DNA-editing enzymes, in $\mathrm{MM}$ tumors carrying $\mathrm{t}(14 ; 16)$. This leads to a mutational pattern termed as APOBEC signature with a high mutation rate ${ }^{[51]}$.

\section{Translocation $\mathrm{t}(14 ; 20)(\mathrm{q} 32 ; \mathrm{q} 12)$}

The translocation $\mathrm{t}(14 ; 20)$ is the rarest of 5 major translocations detected in only $1 \%$ MM patients, and has a poor prognosis. However, paradoxically, long-term stable disease is found in the MGUS and SMM stages $^{[52]}$. It results in over-expression of the $M A F$ gene paralog - $M A F B^{[53]}$. Mutant MAFB is seen in $25 \%$ of patients with $\mathrm{MM}$ harboring $\mathrm{t}(14 ; 20)^{[54]}$. Microarray studies have shown that MAFB over-expression results in $C C N D 2$ deregulation like $c-M A F^{[47]}$. Tumors with $\mathrm{t}(14 ; 20)$ have the APOBEC mutational signature, which is induced by the up-regulated $A P O B E C 4^{[51]}$.

\section{Secondary translocation affecting MYC}

Secondary translocations are independent of class-switch recombination and occur later in the disease ${ }^{[14]}$. The c-MYC proto-oncogenes at $8 \mathrm{q} 24$ is the key target of secondary translocations. c-MYC over-expression is associated with poor prognosis and has a robust correlation to high levels of serum $\beta_{2}$ microglobulin ${ }^{[55]}$. The most common secondary translocation in $\mathrm{MM}$ is $\mathrm{t}(8 ; 14)$, involving the $I G H$ at $14 \mathrm{q} 32.3^{[56]}$. The other partner loci in the remaining $40 \% M Y C$ translocations include IGL at 22q11.2, IGK at 2p11.2, FAM46C at $1 \mathrm{p} 12, \mathrm{FOXO} 3$ at $6 \mathrm{q} 21$, and $B M P 6$ at $6 \mathrm{p} 24.3^{[51]}$. Importantly, all these translocations are unbalanced and associated with kataegis, which is a pattern of localized hypermutation linked with the deregulation of APOBEC activity near the translocation breakpoints. As APOBEC works on single-stranded DNA exposed around the translocation locate, kataegis occurs next to the point of chromosomal rearrangements ${ }^{[1]}$.

\section{COPY NUMBER VARIATIONS}

CNVs involve either gain or loss of DNA. It comprises focal deletions/amplification, chromosomal arm loss/gain, and hyperdiploidy. CNVs contribute to genomic instability either via over-expression of protooncogenes or loss of tumor suppression genes. Therefore, CNVs act as important driver events in MM development and progression ${ }^{[1,3,57]}$.

\section{Hyperdiploidy}

HRD is defined by a chromosome count greater than the diploid number of chromosomes (> 46). In MM, HRD involves trisomies of the odd-numbered chromosomes $(3,5,7,9,11,15,19$, and 21) and is noticed in approximately $50 \%$ of MM cases ${ }^{[51,58,59]}$. The underlying mechanism for HRD is unknown, but one hypothesis suggests that single disastrous mitosis causes the gain of all chromosomes rather than their serial gathering over time ${ }^{[6]}$. However, the contribution of HRD to myelomagenesis is unknown. In addition to the dysfunction of cyclin D genes, GEP studies have validated the involvement of many protein synthesis genes in hyperdiploid tumors. These include MYC, NF- $\kappa \mathrm{B}$, and MAPK signaling pathways ${ }^{[61]}$. From a prognostic perspective, HRD is associated with more favorable survival outcomes than hypodiploidy ${ }^{[62]}$. Furthermore, patients harboring trisomy 3 and trisomy 5 have better overall survival in comparison to trisomy $21^{[63]}$. In contrast, HRD MM with co-existent cytogenetic lesions like del $(17 \mathrm{p}) \mathrm{t}(4 ; 14)$ and gain of $1 \mathrm{q}$ has a poor prognosis compared to HRD MM alone ${ }^{[64]}$. 


\section{Gain of 1q}

The gain of $1 \mathrm{q}$ arm is present in 30 to $40 \%$ of MM cases and is associated with a poor prognosis ${ }^{[14]}$. The amplification process involves 1q12 pericentromeric region instability due to hypomethylation and jumping translocation of the whole $1 \mathrm{q} \mathrm{arm}^{[65]}$. Gene studies have shown a minimally amplified region between $1 \mathrm{q} 21.1$ and 1q23.3 carrying candidate oncogenes including CKS1B, ANP32E, BCL9, PDZK1, ADAR1, PSMD4, $I L F 2, I L 6 R$, and $M C L 1^{[1,66]}$. The protein phosphatase $2 \mathrm{~A}$ inhibitor $A N P 32 E$ involved in chromatin remodeling and transcriptional regulation is independently associated with short survival ${ }^{[67]}$. The identified specific inhibitors of the candidate genes and pathways may help in the treatment of patients with $1 \mathrm{q}$ gain $^{[14]}$.

\section{Loss of $1 p$}

Loss of $1 \mathrm{p}$ is present in $30 \%$ of MM cases and may involve whole arm deletion or interstitial deletion. $1 \mathrm{p}$ loss correlates to poor prognosis ${ }^{[68]} .1 \mathrm{p} 12$ and $1 \mathrm{p} 32.3$ are two important regions involved in myelomagenesis ${ }^{[1]}$. Both these regions experience hemizygous or homozygous deletions ${ }^{[14]}$. Tumor suppressor gene FAM46C is located on $1 \mathrm{p} 12$, and its expression has been verified as positively correlated with ribosomal proteins, eukaryotic initiation, and elongation factors involved in protein translation ${ }^{[7]}$. Similarly, FAF1 and CDKN2C are located on $1 \mathrm{p} 32.3^{[1]}$. The protein encoded by $F A F 1$ is involved in apoptosis initiation via the Fas pathway, while $C D K N 2 C$ is a cyclin-dependent kinase 4 (CDK4) inhibitor which negatively regulates the cell cycle ${ }^{[1]} .1$ p32.3 deletion correlates to a poor prognosis in MM patients undertaking an autologous stem cell transplantation (ASCT) and a neutral prognosis in those receiving non-intensive treatment ${ }^{[68]}$.

\section{Loss of chromosome $13 / 13 q$}

Loss of chromosome 13 is present in 45\%-50\% of MM cases, and primarily in non-HRD tumors. $85 \%$ of cases involve whole $13 \mathrm{q}$ arm deletion whereas $15 \%$ encompass interstitial deletions ${ }^{[14]}$. The minimal deleted region located between 13q14.11 and 13q14.3 also contains some genes related to MM progression, including $R B 1, R C B T B 2, R N A S E H 2 B, E B P L$, mir15a, and mir161. The under-expression of RB1, a tumor suppressor gene, results in negative cell cycle regulation ${ }^{[57]}$. In $90 \%$ of cases, del(13/13q) occurs concurrently with $t(4 ; 14)$ as determined by conventional cytogenetic studies and is linked with poor prognosis ${ }^{[69]}$. In the absence of concurrent lesion, del(13/13q) lacks prognostic significance. Hence, the correlation between $\operatorname{del}(13 / 13 q)$ and poor prognosis can only be seen in some patients with other high-risk genetic lesions ${ }^{[70]}$.

\section{$17 p$ deletion}

The chromosome 17 deletion is a late disease event. It is hemizygous and involves the whole $\mathrm{p} \operatorname{arm}^{[14]}$. The most common gene deregulated in $17 \mathrm{p}$ deletion is the tumor suppressor gene TP5 $3^{[7] 1}$. GEP has shown that monoallelic 17p deletions in MM samples exhibit remarkably lower TP53 compared to non-deleted samples ${ }^{[57]}$. TP53 influences DNA repair, cell cycle arrest, and apoptosis in response to DNA damage as a transcriptional regulator ${ }^{[14]}$. In MM, $17 \mathrm{p}$ deletion is related to more extramedullary involvement, an aggressive disease phenotype, and a shortened life span. It is hypothesized that PCL is the main consequence of TP53 dysfunction ${ }^{[72,73]}$.

\section{Miscellaneous chromosomal gains \& losses}

Focal CNVs have extracted the list of potential driver genes affected by these changes. Gain of 8q24.21 can be discovered in $14 \% \mathrm{MM}$ patients and disturbs MYC genes ${ }^{[1]}$. A gain of 11q13.2 is found in $15 \%$ of patients and involves the oncogene CCND1. CCND1 is also affected by chromosomal translocations and somatic mutations ${ }^{[1]} .11 \mathrm{q}$ deletion is detected in $7 \% \mathrm{MM}$ cases and downregulates tumor suppressor genes BIRC2 and $B I R C 3^{[57]}$. Deletion of $14 \mathrm{q}$ occurs in $38 \%$ of cases and involves TRAF3 (tumor suppressor gene ${ }^{[1]} .16 \mathrm{q}$ deletion is another common event (in $35 \%$ myeloma cases) and reduces the expression of the tumor suppressor genes CYLD and WWOX (implicated in apoptosis) ${ }^{[57]}$. Del(8p) and $\operatorname{del}(12 \mathrm{p})$ are independent 
adverse prognostic markers ${ }^{[14]}$. Del $8 \mathrm{p}$ downregulates the TRAIL gene. TRAIL gene is linked with TNFinduced apoptosis. Its downregulation facilitates the immune escape of malignant clones from cytotoxic $\mathrm{T}$ lymphocytes and natural killer cells ${ }^{[74]}$.

\section{DEREGULATED CELLULAR PATHWAYS}

Several signaling pathways are dys-regulated in MM and contribute towards pathogenesis by influencing proliferation, apoptosis, survival, migration, and drug resistance ${ }^{[75]}$.

\section{NF-KB pathway}

$\mathrm{NF}-\mathrm{\kappa B}$ is a group of transcription factors that play important roles in cell proliferation, differentiation, and survival, as well as in inflammation and immunity ${ }^{[76]}$. The NF- $\mathrm{kB}$ pathway is active in $50 \%$ of MM cases and involves both plasma cells and bone marrow stromal cells (BMSCs) ${ }^{[77]}$. Activation of NF- $\mathrm{kB}$ within MM cells involves either activation of oncogenes or inactivation of tumor suppressor genes in the pathway ${ }^{[78]}$. Genes encoding components of the NFKB pathway include TRAF3, CYLD, LTB, IKBKB, CARD11, BIRC2, BIRC3, and TRAF3IP $1^{[54]}$. The NF- $\mathrm{kB}$ pathway does not influence the survival in $\mathrm{MM}^{[14]}$. The pathway involves the proteasome protein complex, thereby suggesting the role of proteasome inhibitors in MM treatment ${ }^{[78]}$.

\section{Cell proliferation pathways}

The cell proliferation pathways in MM include the MAPK pathway, the JAK-STAT pathway, and the phosphatidylinositol-3 kinase (PI3K) pathway.

\section{The MAPK pathway}

The MAPK pathway is a chain of proteins that communicate signals from cell surface receptors to the DNA in the cell nucleus ${ }^{[79]}$. The pathway is activated from inflammatory cytokines TNF-a, IL-6, and IGF-1 and, in return, triggers the downstream kinase cascades RAS, RAF, MEK, and MAPK, thus regulating gene expression. Two dominant oncogenes involved in this pathway include NRAS and KRAS ${ }^{[80]}$. Their mutations are frequently subclonal and are involved in disease progression. RAS mutations indicate a poor prognosis, aggressive phenotype, and shortened survival ${ }^{[5]}$. The involvement of $R A S$ mutations across various cancers has given insight into the research on therapeutic inhibitors within this area ${ }^{[14]}$. Likewise, activation of mutation in the BRAF-MAPK signaling pathway, which encodes serine/threonine-protein kinase suggests the potential use of BRAF inhibitors in MM patients with BRAF mutations ${ }^{[81]}$.

\section{The JAK-STAT pathway}

The JAK-STAT pathway is activated in both MM cells and BMSCs in approximately $50 \%$ of cases ${ }^{[82]}$. Cytokine IL-6 signaling induces JAK-STAT activation and myelomagenesis ${ }^{[14]}$. The over-activation of STAT3, a STAT family transcription factor, causes over-expression of Bcl-x an anti-apoptotic protein, and therefore triggers chemoresistance ${ }^{[83]}$. The in vitro inhibition of STAT3 with atiprimod, curcumin, and the JAK2 kinase inhibitor AG490 have already shown fair results for inhibition of IL-6-induced MM survival ${ }^{[84]}$. In addition, STAT3 inhibition has shown sensitization of the U266 cell line to apoptosis from conventional chemotherapy agents ${ }^{[85]}$. Hence, these results highlight the prospective conjoined role of STAT3 inhibitors and conventional chemotherapy in myeloma treatment ${ }^{[14]}$.

\section{The PIsK pathway}

PI3K-Akt is a signal transduction pathway that supports cell growth and survival in response to extracellular signal $^{[86]}$. The PI3K (phosphatidylinositol 3-kinase) gets activated with IL-6 and IGF-1 action on tyrosine kinase receptors, leading to phosphorylation of the serine-threonine-specific kinase AKT (serine/threonine kinase). AKT, in return, activates its downstream genes, including mTOR, GSK-3B, and FKHR, therefore 
regulating cell proliferation and apoptosis resistance ${ }^{[14]}$. The phosphorylated AKT is a marker indicative of pathway activity, which is observed in approximately $50 \%$ of $\mathrm{MM}_{\text {cases }}{ }^{[87]}$. Therapeutic targeting of $\mathrm{PI} 3 \mathrm{~K}$ is an area of interest in MM research ${ }^{[14]}$.

\section{Cell cycle deregulation}

The deregulation of the G1/S cell cycle transition point via cyclin D gene overexpression is central to an early molecular abnormality in $\mathrm{MM}^{[14]}$. Additionally, the defect of negative cell cycle regulatory genes is another major event that destabilizes cell cycle regulation. CDKN2C (Cyclin-Dependent Kinase Inhibitor $2 \mathrm{C})$ downregulation either by $1 \mathrm{p}$ deletion or DNA methylation deregulates the G1/S transition ${ }^{[68]}$. Similarly, CDK inhibitors p15, p16, and p18 are important in the regulation of progression through the cell cycle. Studies have shown that hypermethylation and homozygous deletions of p15, p16, and p18 genes lead to uncontrolled growth and MM progression ${ }^{[88]}$. Treatment with the demethylating agent 5-deoxycytidine restores p16 protein expression and induces $\mathrm{G}_{1}$ growth arrest in $\mathrm{MM}$ cell lines ${ }^{[75]}$. p21, another potent cyclin-dependent kinase inhibitor, binds to and inhibits the activity of CDK2, CDK1, and CDK4/6 complexes. It protects the MM cells from apoptosis by the induction of cell cycle arrest and subsequent DNA repair, hence inducing resistance to apoptosis by chemotherapy and radiotherapy ${ }^{[89]}$. Furthermore, $R B 1$ (tumor suppressor gene) inactivation also affects the G1/S transition and may occur because of monosomy 13, homozygous deletion, or mutational inactivation ${ }^{[57]}$.

\section{Defective DNA repair}

The DNA repair score is a predictive factor for progression-free and overall survival of MM patients. The score's strength is based upon the influence of aberrant DNA repair in $\mathrm{MM}^{[00]}$. The understanding of DNA repair mechanisms in MM is important for developing therapeutic approaches based on the concept of synthetic lethality. It states that a combination of deficiencies in two genes (e.g., gene X and a DNA repair gene) causes cell death, whereas a deficiency in only one of the genes (gene X) does not ${ }^{[3]}$. For example, poly ADP-ribose polymerase (PARP) inhibitors are used to treat solid tumors deficient in BRCA1 and BRCA2 function, which are important for maintaining the error-free homologous recombination (HR) pathway of DNA repair. PARP is a family of proteins involved in several cellular processes (e.g., DNA repair, genomic stability, and programmed cell death). PARP1 expression is linked with shortened survival and high-risk disease in MM patients ${ }^{[91]}$. PARP inhibitors have given promising results in cancers with defective HRmediated DNA repair mechanisms, as MM backbone drugs proteasome inhibitors (e.g., bortezomib) affect the apoptotic sensitivity of MM cells ${ }^{[91]}$. Therefore, bortezomib-induced impairment of homologous recombination in MM cells can pharmacologically sensitize them to PARP inhibition, resulting in synthetic lethality ${ }^{[91]}$. We recently found that a noncoding RNA MALAT1 is critical for PARP1 binding to LIG3 to mitigate an alternative end-joining DNA repair pathway and may serve as a novel therapeutic target for $\mathrm{MM}^{[92,93]}$.

\section{Abnormal RNA editing}

Post-transcriptional RNA processing is important for the maintenance of genomic stability in $\mathrm{MM}^{[94]}$. MM patients may harbor mutations in genes controlling RNA processing and protein translation. DIS 3 gene on 13q22.1 encodes an exonuclease involved in regulating the abundance of RNA species. In MM patients, loss of DIS3 function is linked to monoallelic mutation or deletion. Exosomes play a vital role in regulating the mRNA pool. Therefore, loss of DIS3 activity may contribute to oncogenesis of MM due to protein translation deregulation. Similarly, the role of FAM46C in translational control and recurrent mutation in myelomagenesis is of biological relevance ${ }^{[95]}$. RNA processing includes splicing pattern modification of transcripts involved in DNA repair ${ }^{[96]}$. This alternative splicing of DNA repair depends upon the proper activity of RNA-binding proteins (RBPs) ${ }^{[97]}$. Genetically aggressive myeloma patients who have 1q21 amplification usually have 1q21-induced over-expression of the RBP-ILF2 (interleukin enhancer-binding 
factor 2). As ILF2 is a key regulator in HR repair in MM, high ILF2 expression promotes resistance to genotoxic reagents by modulating the translocation of YB1 (Y-box binding protein 1). Therefore, blocking the ILF2 signaling pathway may improve the effect of DNA-damaging agents in MM therapy ${ }^{[98]}$.

\section{Deregulated plasma cell differentiation}

IRF4 (interferon regulatory factor 4), also known as MUM1, is involved in the regulation of interferon transcription and $\mathrm{B}$ cell proliferation and differentiation ${ }^{[14]}$. An in vitro RNA-interference study discovered that IRF4 is necessary for the survival of MM cell lines ${ }^{[99]}$. IRF4 is also important therapeutically, as the backbone MM drug lenalidomide indirectly downregulates IRF4 by downregulating cereblon, the primary target of the CRBN-IKFZ1/3-IRF4-MYC pathway ${ }^{[100,101]}$. IRF4 acts as a transcription factor for BLIMP1, another transcription factor pivotal in plasma cell differentiation. A study by Chapman et al. ${ }^{[7]}$ identified 2 out of 38 patients with MM harboring an identical mutation (K123R) in the DNA-binding domain of IRF4. The same study group also harbored loss of function mutations in BLIMP1 usually identified in diffuse large B-cell lymphoma ${ }^{[7,102]}$. However, the role of differentiation pathway dysfunction in myelomagenesis needs further investigation as MM is a malignancy of terminally differentiated plasma cells.

\section{Bone disease in myeloma}

Bone disease in $M M$ is associated with shorter overall survival and presents as focal/diffuse pain, pathological fractures, cord compression, and hypercalcemia. It is common in patients with hyperdiploidy, $\mathrm{t}(4 ; 14)$, and $M A F$ translocations ${ }^{[103]}$. A recent GEP study has identified approx. 50 genes linked with bone disease, with DKK1 and FRZB being the most prominent. DKK1 and FRZB are Wnt pathway inhibitors and induce osteoblast differentiation inhibition and increase bone resorption via RANKL/OPG ratio imbalance ${ }^{[104,105]}$. The antibody against DKK1 is an important therapeutic area to approach bone disease in MM patients. Anti-DKK1 antibody has resulted in improved bone disease outcomes and myeloma cell growth inhibition in pre-clinical models ${ }^{[106]}$.

\section{EPIGENETIC MODIFICATIONS}

First, genomic instability is the hallmark of MM, and dysfunctional DNA damage response is one of the many driving contributing factors ${ }^{[3]}$. SIRT6 (NAD-dependent deacetylase) is highly expressed in MM cells and is linked with poor prognosis. Its expression is an adaptive response to maintain genomic stability. SIRT6 interacts with the promoter area of transcription factor ELK1 and ERK signaling-related genes. SIRT6 also downregulates the MAPK pathway gene expression and signaling. Moreover, the inactivation of ERK2 signaling increases DNA repair via checkpoint kinase 1 and confers resistance to DNA damage ${ }^{[107]}$. RecQ helicase, a DNA unwinding enzyme, is involved in maintaining chromosome stability. MM cells have a higher expression of RECQ1, which is associated with poor prognosis. RECQ1 over-expression helps MM cells escape from cytotoxicity of melphalan and bortezomib. On the contrary, knockdown of RECQ1 suppresses cell growth and stimulates apoptosis in MM cells; RECQ1 depletion promotes double-strand breaks on DNA in MM cells and sensitizes them to PARP inhibitors. RECQ1 downregulation can also be induced by DNMT inhibitor treatment through dysregulation of miR-203 in MM. Hence, PARP inhibitors combined with DNMT inhibitors constitute an important therapeutic approach for MM patients ${ }^{[3,108]}$.

The HOXA9 gene encodes a DNA-binding transcription factor involved in cell differentiation, morphogenesis, and gene expression regulation. It is regulated by histone methyltransferases, and knockdown of it in MM cell lines incurs a competitive disadvantage as compared to those with intact HOXA9 gene expression. This indicates the role of HOXA9 expression in myelomagenesis and the utilization of epigenetic changes for devising new therapeutic targets in $\mathrm{MM}^{[7]}$. 
Secondly, studies have revealed that miRNAs may act as both tumor suppressors and oncogenes in various cancers. Substantial work has been done to investigate the role of miRNAs in MM. Studies indicate that miRNAs can negatively regulate genes and pathways relevant to myelomagenesis via transcriptional control through promoter methylation ${ }^{[14]}$. For example, miR-137 maintains genomic instability in an aurora kinase A (AURKA)-dependent manner, while miR-22 regulates DNA ligase III in $\mathrm{MM}^{[109,110]}$. In short, miRNA deregulation is a key contributor to malignancy, and further research will unravel potential treatment targets.

Third, DNA methylation regulates gene expression and contributes to MM progression from MGUS to PCL. DNA methylation is found at higher frequencies in promoter regions, repeat sequences, and transposable elements of genes. MM has a recognized pattern of global DNA hypomethylation and genespecific hypermethylation affecting cell adhesion, proliferation, the stromal-clone relationship, cell cycle progression, and transcription, predominantly in $\mathrm{t}(4 ; 14)$ tumors, resulting in MMSET gene overexpression $^{[111]}$.

\section{CLONAL HETEROGENEITY}

Intraclonal heterogeneity is a common feature of MM and occurs in the milieu of selection events in the tumor microenvironment ${ }^{[1]}$. The clonal evolution in MM follows the Darwinian model, which involves the random acquisition of genetic changes that offer a survival advantage ${ }^{[14]}$. WES sequencing analysis shows that clonal heterogeneity begins from a premalignant stage and follows either linear or branching evolution patterns. Linear evolution involves the emergence of a new subclone or predominance of a pre-existing subclone, resulting in the stepwise acquisition of driver mutations. Branching evolution involves the emergence of one or more subclones via divergent mutational pathways, while other subclones decline in frequency or disappear ${ }^{[2]}$. Another factor is clonal stability, where similar clonal and subclonal heterogeneity is found before and after treatment, which would equally repopulate the tumor. The study of intraclonal heterogeneity is important to improve the understanding of disease pathogenesis, as the genetic aberrations in the predominant clonal population at the time of sampling may not apply to all subclonal populations. Thus, such heterogeneity may explain relapse and drug resistance to anticancer treatments ${ }^{[14]}$.

\section{BONE MARROW MICROENVIRONMENT}

A complex interaction exists between malignant plasma cells and non-malignant stromal cells in the bone marrow microenvironment. This interaction involves adhesion molecules and autocrine/paracrine cytokine signaling. The cytokines secreted by the stromal cells include IL-6, VEGF, IL-1b, IL-10, TNF-a, TGF-b, MMP-1, osteoprotegerin (OPG)/RANKL MIP-1a, FGFs, and IGFs ${ }^{[112]}$. IL-6 is the most significant with a role in B cell differentiation; however, in MM, it induces proliferation and apoptosis inhibition. The IL- 6 receptor has two subunits: IL-6Ra and gp130 (a transmembrane signal transducer). IL-6 combines with IL$\mathrm{Ra}$, which then mediates signals via gp130. IL-Ra subunit has an agonist action. In contrast, gp130 may competitively inhibit the growth-promoting effects of IL-6/IL-6R complex at higher concentrations ${ }^{[113]}$. IL-6-IL-6R interaction activates 3 downstream pathways: STAT1/STAT3 pathway, STAT3/STAT3 pathway, and Ras/MAPK pathway ${ }^{[114]}$.

Similarly, VEGF, FGFs, and HGFs play a role in angiogenesis and IL-1b, RANKL, and HGFs in osteoclast activation. TNF-a, IGFs, IL-1b, and VEGF have a direct effect on MM cells ${ }^{[75]}$. Some factors secreted by bone marrow are known to influence the efficacy of chemo and radiation therapy and have a role in disease progression. For example, MM cell interaction with fibronectin in the extracellular matrix up-regulates p27, which induces drug resistance ${ }^{[115]}$. Likewise, the binding of MM cells to hyaluronic acid synergizes IL-6 signaling and reduction in adhesion molecules CD56; very late antigen 4 facilitates the transition to the 
extramedullary phase ${ }^{[75]}$.

\section{MULTIPLE MYELOMA TREATMENT}

ASCT is standard care for MM. However, the foremost decision in MM patient management is ASCT eligibility. Patients less than 65 years of age with no severe comorbidities are usually eligible for ASCT. Furthermore, no definitive clinical data is available to support that ASCT is better in the early stage of disease than in later/relapsed cases ${ }^{[116]}$. All transplant-eligible MM patients must receive primary induction therapy. The induction therapy combination regimens are given in Table 2.

Lenalidomide is a derivative of thalidomide, which is also an immunomodulatory drug (IMiD) but has more powerful anti-tumor and anti-inflammatory effects. It induces MM cell growth arrest, binding inhibition to BM-ECM and stromal cells, and downregulation of IL- 6 and NF- $\mathrm{KB}^{[117]}$. While lenalidomide has a partial response rate of $24 \%-29 \%$ in treatment-refractory MM patients, combinatory lenalidomide and dexamethasone has peaked partial remission to an additional $29 \%$ in the lenalidomide-responsive patient $\operatorname{group}^{[118]}$.

Over time, more powerful triplet combinations of lenalidomide/dexamethasone with a monoclonal antibody (elotuzumab - anti-CD319, daratumumab - anti-CD38) or a PI (bortezomib, carfilzomib, ixazomib) have evolved with significant improvement in the progression-free survival (PFS) and overall survival $(\mathrm{OS})^{[119,120]}$. Combination treatment strategies apply the concept of using therapies with distinct mechanisms of action ${ }^{[121]}$. The triple combination therapy trials of proteasome inhibitor and monoclonal antibodies are summarized in Tables 3 and 4.

Once remission is achieved, stem cells are harvested via apheresis. Maintenance therapy after transplantation includes (1) oral lenalidomide - $10 \mathrm{mg} /$ day for the first 3 months; (2) oral Ixazomib - $3 \mathrm{mg}$ on day 1,8 , and 15 in 28-day cycles in cycles 1 through 4 and increased to $4 \mathrm{mg}$ from cycle 5 if tolerated; and (3) intravenous bortezomib $-1.3 \mathrm{mg} / \mathrm{m}^{2}$ on days $1,4,8$ and 11 every 3 months.

Despite these treatment advancements, a considerable number of MM patients have shown resistance to PI, IMiDs, and monoclonal antibodies. A retrospective study has revealed that refractoriness results in only 5.6 months median OS in MM patients ${ }^{[110]}$. Hence, there is an urgent need to devise more effective therapeutic interventions for this patient population ${ }^{[121,122]}$.

\section{Conventional chemotherapy}

Conventional chemotherapy can serve as salvage therapy in relapsed/refractory MM (RRMM) patients nonresponsive to the triple-drug combination therapies. Due to intense toxicity, these cytoreduction agents are used for short periods of time and serve best as a bridge to more effective therapies ${ }^{[121]}$. A study of dexamethasone without thalidomide administration with an infusion of cisplatin, doxorubicin, cyclophosphamide, and etoposide [D(T)PACE] resulted in an overall response rate (ORR) of 49\%, median PFS of 5.5 months, and OS of 14 months ${ }^{[123]}$. Among patients that proceeded to ASCT, median PFS was 13.4 months, and OS was 20.5 months. Another study compared the outcome of three chemotherapy regimens (1) dexamethasone, cyclophosphamide, etoposide, and cisplatin; (2) bortezomib, thalidomide, dexamethasone, cisplatin, doxorubicin, cyclophosphamide, and etoposide (VTD-PACE); and (3) cyclophosphamide, vincristine, doxorubicin, and dexamethasone (CVAD) in RRMM. The three salvage regimens demonstrated similar overall RR (55\%), PFS (4.5 months), and OS (8.5 months) $)^{[124]}$. 
Table 2. Induction therapy for transplant-eligible patients

1. Lenalidomide/Dexamethasone

2. Bortezomib/Thalidomide/Dexamethasone

3. Bortezomib/Lenalidomide (Revlimid)/Dexamethasone (VRd, RVd)

4. Bortezomib/Doxorubicin/Dexamethasone

5. Bortezomib/Cyclophosphamide/Dexamethasone (CyBorD, VCD)

6. Daratumumab/Bortezomib/Thalidomide/Dexamethasone (dara-VTD)

Table 3. Triple combination monoclonal antibody with lenalidomide and dexamethasone trials

\begin{tabular}{|c|c|c|c|}
\hline Trial title & Trial ID & Phase & Treatment \\
\hline AMN006 & NCT03695744 & $\|$ & Daratumumab + Bortezomib + Dexamethasone \\
\hline CANDOR & NCT03158688 & III & Daratumumab + Carfilzomib + Dexamethasone \\
\hline $\begin{array}{l}\text { Phase III trial comparing Poma, Dexa with/without Dara in } \\
\text { RRMM with } 1 \text { prior therapy but not Lenalidomide \& PI }\end{array}$ & NCT03180736 & III & Daratumumab + Pomalidomide + Dexamethasone \\
\hline VELCADE & NCT02541383 & III & $\begin{array}{l}\text { Daratumumab + Bortezomib + Thalidomide + } \\
\text { Dexamethasone }\end{array}$ \\
\hline CASTOR & NCT02136134 & III & Daratumumab + Bortezomib + Dexamethasone \\
\hline POLLUX & NCT02076009 & III & Daratumumab + Dexamethasone + Lenalidomide \\
\hline ALCYONE & NCT02195479 & III & $\begin{array}{l}\text { Daratumumab + Melphalan + Bortezomib + } \\
\text { Prednisolone/Dexamethasone }\end{array}$ \\
\hline $\begin{array}{l}\text { Phase II single-arm study of Elotuzumab with Lenalidomide + } \\
\text { Dexamethasone in newly diagnosed or RRMM }\end{array}$ & NCT02159365 & $\|$ & Elotuzumab + Lenalidomide + Dexamethasone \\
\hline $\begin{array}{l}\text { Phase II study of elotuzumab in combination with Poma, Bort, \& } \\
\text { Dexa in RRMM }\end{array}$ & NCT02718833 & $\|$ & $\begin{array}{l}\text { Elotuzumab + Pomalidomide + Bortezomib }+ \\
\text { Dexamethasone }\end{array}$ \\
\hline Single arm open-label anti-SLAMF7 mAB therapy after ASCT & NCT03168100 & $\|$ & $\begin{array}{l}\text { Elotuzumab + Bortezomib + Lenalidomide + } \\
\text { Dexamethasone }\end{array}$ \\
\hline ELOQUENT 3 & NCT02654132 & $\|$ & Elotuzumab + Pomalidomide + Dexamethasone \\
\hline HRMM & NCT01668719 & I/II & $\begin{array}{l}\text { Bortezomib + Lenalidomide + Dexamethasone }+/ \text { - } \\
\text { Elotuzumab }\end{array}$ \\
\hline ELOQUENT 2 & NCT01239797 & III & Lenalidomide + Dexamethasone +/- Elotuzumab \\
\hline
\end{tabular}

RRMM: Relapsed refractory multiple myeloma; PI: proteasome inhibitor, Poma: pomalidomide; Dexa: dexamethasone; Bor: bortezomib; mAB: monoclonal antibody.

Table 4. Proteasome inhibitor combination therapy trials

\begin{tabular}{|c|c|c|}
\hline Trial title & Phase & Treatment \\
\hline IFM2005-01 & III & Bortezomib + Dexamethasone vs. Vincristine + Doxorubicin + Dexamethasone \\
\hline DSSM-XI & II & Bortezomib + Cyclophosphamide + Dexamethasone \\
\hline GIMEMA & III & Bortezomib + Thalidomide + Dexamethasone vs. Thalidomide + Dexamethasone \\
\hline GEM05-MENOS65 & III & $\begin{array}{l}\text { Bortezomib + Thalidomide + Dexamethasone vs. Thalidomide + Dexamethasone vs. Chemotherapy + } \\
\text { Bortezomib }\end{array}$ \\
\hline IFM2013-04 & III & Bortezomib + Thalidomide + Dexamethasone vs. Bortezomib + Cyclophosphamide + Dexamethasone \\
\hline $\begin{array}{l}\text { HOVON-65/GMMG- } \\
\text { HD4 }\end{array}$ & III & Doxorubicin + Bortezomib + Dexamethasone vs. Vincristine + Doxorubicin + Dexamethasone \\
\hline IFM2009 & III & Bortezomib + Lenalidomide + Dexamethasone +/- ASCT \\
\hline CASSIOPEIA & III & $\begin{array}{l}\text { Daratumumab + Bortezomib + Thalidomide + Dexamethasone vs. Bortezomib + Thalidomide + } \\
\text { Dexamethasone }\end{array}$ \\
\hline ENDEAVOR & III & Carfilzomib + Dexamethasone vs. Bortezomib + Dexamethasone \\
\hline A.R.R.O.W & III & Weekly vs. Biweekly Carfilzomib + Dexamethasone \\
\hline ASPIRE & III & Carfilzomib + Lenalidomide + Dexamethasone vs. Lenalidomide + Dexamethasone \\
\hline DKd & $1 b$ & Daratumumab + Carfilzomib + Dexamethasone \\
\hline TOURMALINE-MM1 & III & Ixazomib + Lenalidomide + Dexamethasone vs. Bortezomib + Dexamethasone \\
\hline
\end{tabular}


Bendamustine is a bifunctional alkylating agent. A retrospective study of bendamustine monotherapy and corticosteroid combination has resulted in 3\% "very good" partial response, 33\% partial response, $26 \%$ stable disease, and $20 \%$ progressive disease, along with a median PFS of 7 months and OS of 17 months in $\mathrm{RRMM}^{[125]}$. The combination regimens of bendamustine with thalidomide, lenalidomide plus dexamethasone, and bortezomib plus dexamethasone have also demonstrated good tolerability and improved efficacy in early trials of $\operatorname{RRMM}^{[126,127]}$.

Histone deacetylase inhibitors (HDACi) target the effects of epigenetic modification and have demonstrated positive outcomes in RRMM patients, especially when used in combination with PIs. In the phase III PANORAMA-1 trial, RRMM patients received panobinostat plus bortezomib and dexamethasone versus placebo plus bortezomib and dexamethasone. The results demonstrated a clinically significant improvement with a median PFS of 11.99 months vs. 8.08 months $^{[128]}$. Similarly, the PANORAMA-2 trial tested panobinostat combination therapy in bortezomib-refractory patients with a subsequent $34.5 \%$ ORR and 6 months median response duration ${ }^{[129]}$. Another HDACi vorinostat was tested in the VANTAGE 095 trial involving heavily pretreated RRMM refractory to bortezomib and immunomodulators. A combination of vorinostat and bortezomib resulted in an ORR of 17\%, median response duration of 6.3 months, PFS of 3.1 months, and OS of 11.2 months $^{[130]}$. Furthermore, the phase III VANTAGE 088 trial compared the outcome of vorinostat plus bortezomib with the bortezomib group alone. The study's results included a PFS of 7.63 months vs 6.83 months and an ORR of $56.2 \%$ vs $40.6 \%^{[131]}$.

\section{Salvage ASCT}

Salvage ASCT is an important therapeutic choice for RRMM. Several retrospective studies have demonstrated post-reinduction salvage ASCT success in MM patients who relapsed after first ASCT or RVD-alone treatment ${ }^{[132]}$. Although most patients with RRMM were not candidates for salvage ASCT due to age and comorbidities, those who underwent salvage ASCT exhibited a PFS of 7 to 22 months. The foremost factor predicting improved PFS and OS after salvage ASCT is the duration of remission after initial $\operatorname{ASCT}^{[121]}$.

\section{Selinexor}

Selinexor is an oral, slowly reversible, first-in-class, potent selective inhibitor of nuclear export compound that specifically blocks exportin 1 (XPO1). The Food and Drug Administration has approved selinexor for RRMM patients who have had 4 previous therapies and disease refractoriness to 2 PIs, 2 IMiD agents, and anti-CD38 $\mathrm{mAb}^{[133]}$. The Selinexor trials are summarized in Table 5.

\section{Immunotherapies for multiple myeloma}

Advances in cellular immunotherapy - CAR (chimeric antigen receptor) T-cell therapy, B cell maturation antigen (BCMA)-targeted therapies, and bispecific $\mathrm{T}$ cell engager (BiTE) and tri-specific $\mathrm{T}$ cell engager (TiTE) - have good prospects in MM therapy ${ }^{[121]}$. In CAR T-cell therapy, $\mathrm{T}$ cells are modified to express CARs genetically through introducing fusion proteins that have an antigen recognition region and a costimulation domain. CAR T-cells targeting BCMA, CD138, CS1 glycoprotein antigen (SLAMF7), and light chains are in active development for RRMM treatment ${ }^{[134]}$. BCMA is a type of surface receptor, which belongs to the tumor necrosis factor superfamily. It is expressed in advanced B cell differentiation stages, and predominantly in plasma cells. Several BCMA-targeted therapeutics, including antibody-drug conjugates (e.g., belantamab mafodotin GSK2857916), CAR-T cells, BiTEs, and TiTE have also resulted in incredible clinical response in $\mathrm{RRMM}^{[135]}$. Tables 6 and 7 summarize immunotherapy clinical trials for MM. 
Table 5. Selinexor combination trials

\begin{tabular}{|c|c|c|c|c|}
\hline Trial title & Phase & Drug combination & Dose & Results \\
\hline $\begin{array}{l}\text { STORM Trial } \\
\text { NCT02336815 }\end{array}$ & II & Selinexor + Dexamethasone & $\begin{array}{l}\text { Selinexor - } 80 \mathrm{mg} \text { oral day } 1 \& 3 \text { of } \\
\text { each week } \\
\text { Dexa - } 20 \mathrm{mg} \text { prior to each dose }\end{array}$ & $\begin{array}{l}\text { Partial response } 26 \% \\
\text { Clinical benefit rate (CBR) } 39 \% \\
\text { Median response duration } 4.4 \text { months } \\
\text { Median PFS } 3.7 \text { months } \\
\text { Median OS } 8.6 \text { months } \\
\text { Pt with molecular response had medial OS } \\
\text { of } 15.6 \text { months }\end{array}$ \\
\hline $\begin{array}{l}\text { BOSTON Trial } \\
\text { NCT03110562 }\end{array}$ & III & $\begin{array}{l}\text { Selinexor + Dexamethasone + } \\
\text { Bortezomib (SVd) }\end{array}$ & $\begin{array}{l}\text { Selinexor - } 100 \mathrm{mg} \text { once weekly } \\
\text { Dexa - } 40 \mathrm{mg} \text { weekly } \\
\text { Bortezomib }-1.3 \mathrm{mg} / \mathrm{m}^{2}\end{array}$ & $\begin{array}{l}\text { PFS } 13.93 \text { months in SVd arm vs. } 9.46 \\
\text { months in Vd arm }\end{array}$ \\
\hline
\end{tabular}

Further, 10 combination therapies of Selinexor in 11 treatment arms are under investigation in the STOMP Trial (NCT02343042).

Table 6. BCMA and non-BCMA CAR - T cell clinical trials in MM

\begin{tabular}{|c|c|c|c|c|}
\hline Clinical trial & Phase & $\begin{array}{l}\text { No. of } \\
\text { Pt. }\end{array}$ & Dose & Outcome \\
\hline $\begin{array}{l}\text { Anti-BCMA CAR-T cell } \\
\text { (NCT02215967) }\end{array}$ & 1 & 12 & $\begin{array}{l}0.3,1.0,3.0,9.0 \times 10^{6} \mathrm{CAR} \\
\text { cells } / \mathrm{kg}\end{array}$ & PR 3, SD 8, sCR 1 \\
\hline $\begin{array}{l}\text { bb2121 Anti-BCMA CAR-T cell } \\
\text { (NCT02658929) }\end{array}$ & । & 33 & $\begin{array}{l}50,150,450 \text {, or } 800 \times 10^{6} \\
\text { CART cells }\end{array}$ & $\begin{array}{l}\text { ORR } 85 \% \text {, sCR } 12 \text {, CR 3, VGPR 9, PR 4, } \\
\text { SD 4, PD } 1\end{array}$ \\
\hline $\begin{array}{l}\text { bb21217 Anti-BCMA CAR-T cell } \\
\text { (NCT03274219) }\end{array}$ & । & 8 & $150 \times 10^{6}$ CAR T cells & sCR 1, VGPR 3, PR 2, -ve MRD 3 \\
\hline $\begin{array}{l}\text { LCAR-B38M Anti-BCMA CAR-T cell } \\
\text { (ChiCTR-ONH-17012285) }\end{array}$ & । & 17 & $0.21-1.52 \times 10^{6} \mathrm{CAR}$ T cells $/ \mathrm{kg}$ & ORR $88.2 \%$, sCR 13 , VGPR 2, NR 1 \\
\hline $\begin{array}{l}\text { LCAR-B38M Anti-BCMA CAR-T cell } \\
\text { (NCT03090659) } \\
\text { LEGEND-2 Trial }\end{array}$ & I/II & 57 & $0.07-2.1 \times 10^{6} \mathrm{CAR} T$ cells $/ \mathrm{kg}$ & $\begin{array}{l}\text { ORR: } 88 \% \text {, CR 39; VGPR 3, PR 8, -ve } \\
\text { MRD } 36\end{array}$ \\
\hline $\begin{array}{l}\text { JCARH125 Anti-BCMA CAR-T cell } \\
\text { (NCT03430011) } \\
\text { EVOLVE Trial }\end{array}$ & I/II & 19 & $50-150 \times 10^{6}$ CAR T cells $/ \mathrm{kg}$ & sCR 2, CR 1, VGPR 2, PR 2, MR1 \\
\hline $\begin{array}{l}\text { CT053 Anti-BCMA CAR-T cell } \\
\text { (NCT03915184) }\end{array}$ & - & 16 & $0.5-1.8 \times 10^{8}$ CAR T cells & ORR $100 \%$, CR 2, PR 4, VGPR 6 \\
\hline $\begin{array}{l}\text { MCARH171 Anti-BCMA CAR-T cell } \\
\text { (NCT03070327) }\end{array}$ & । & 11 & $\begin{array}{l}72,137,475,818 \times 10^{6} \text { CAR T } \\
\text { cells }\end{array}$ & ORR $64 \%$, VGPR 2 \\
\hline $\begin{array}{l}\text { CT103A Anti-BCMA CAR-T } \\
\text { (ChiCTR1800018137) }\end{array}$ & । & 9 & $1,3,6 \times 10^{6} \mathrm{CAR}$ T cells $/ \mathrm{kg}$ & ORR $100 \%$, CR 4; VGPR1, PR 4 \\
\hline $\begin{array}{l}\text { CD3 \& \& 4-1BB Anti-BCMA CAR-T cell } \\
\text { (NCT02546167) }\end{array}$ & । & 25 & $1-50 \times 10^{7}$ CAR T cells & SCR 1, CR 1, VGPR 5, PR 5 \\
\hline $\begin{array}{l}\text { P-BCMA-101 CAR-T cell } \\
\text { (NCT03288493) }\end{array}$ & । & 12 & $48-430 \times 10^{6} \mathrm{CAR}+\mathrm{T}$ cells & sCR 1, nCR 1, VGPR 1, PR 2 \\
\hline $\begin{array}{l}\text { CD4+: CD8+ BCMA CAR-T cell } \\
\text { (NCT03338972) }\end{array}$ & । & 7 & $5-15 \times 10^{7}$ CAR T cells & ORR $100 \%$ \\
\hline $\begin{array}{l}\text { Anti-CD19 non-BCMA CAR-T cell } \\
\text { (NCT02135406) }\end{array}$ & । & 10 & $1.1-6.0 \times 10^{8}$ CAR T cells & VGPR 6, PR 2; PD 2 \\
\hline $\begin{array}{l}\text { Anti-CD138 non-BCMA CAR-T cell } \\
\text { (NCT01886976) }\end{array}$ & I/II & 5 & $0.44-1.51 \times 10^{7} \mathrm{CAR}+\mathrm{T}$ cells $/ \mathrm{kg}$ & $\mathrm{SD} 4, \mathrm{PD} 1$ \\
\hline $\begin{array}{l}\kappa \text { light chain non-BCMA CAR-T cell } \\
\text { (NCT00881920) }\end{array}$ & । & $\begin{array}{l}16 \\
(7 \mathrm{MM})\end{array}$ & $0.2-2.0 \times 10^{8} \mathrm{CAR}+\mathrm{T}$ cells $/ \mathrm{m}^{2}$ & $4 \mathrm{SD}$ of $7 \mathrm{MM}$ \\
\hline
\end{tabular}

ORR: Overall response rate; VGPR: very good partial response; CR: complete response; PR: partial response; sCR: stringent complete response; MRD: minimal residual disease.

\section{Targeted therapy for multiple myeloma}

Clonal heterogeneity and clonal competition in the MM cancer cells have signified the role of targeted therapy (precision medicine) in patient management. Therefore, the identification of driver mutations is central to designing personalized targeted therapy. In addition, novel vaccines and immune-checkpoint 
Table 7. BCMA targeted ADC and bispecific T-cell therapy clinical trials

\begin{tabular}{|c|c|c|c|c|}
\hline Clinical trial & Phase & $\begin{array}{l}\text { No. of } \\
\text { Patients }\end{array}$ & Dose & Outcome \\
\hline $\begin{array}{l}\text { Belantamab mafodotin } \\
\text { (GSK2857916) }\end{array}$ & I & 35 & $3.4 \mathrm{mg} / \mathrm{kg}$ every 3 weeks & $\begin{array}{l}\text { ORR 60\%, sCR } 2(6 \%), \text { CR } 3 \\
(9 \%), \text { VGPR } 14(40 \%), \text { mPFS }\end{array}$ \\
\hline DREAMM-1 (NCT02064387) & & & & 12 months, mDOR 14.3 months \\
\hline \multirow[t]{2}{*}{ DREAMM-2 (NCT03525678) } & II & 196 & 2.5 or $3.4 \mathrm{mg} / \mathrm{kg}$ every 3 weeks & $\begin{array}{l}\mathbf{2 . 5} \mathbf{~ m g} / \mathbf{k g} \text { cohort } \\
\text { ORR } 30 \text { (31\%), sCR/CR } 3(3 \%), \\
\text { VGPR } 15(15 \%), \text { PD } 56(58 \%), \\
\text { mPFS } 2.9 \text { months }\end{array}$ \\
\hline & & & & $\begin{array}{l}\mathbf{3 . 4} \mathbf{~ m g} / \mathbf{k g} \text { cohort } \\
\text { ORR } 34 \text { (34\%), sCR/CR } 3 \text { (3\%), } \\
\text { VGPR } 17(17 \%), \text { PD } 55 \text { (56\%), } \\
\text { mPFS } 4.9 \text { months }\end{array}$ \\
\hline $\begin{array}{l}\text { BCMA/CD3 (AMG 420) } \\
(\text { NCTO2514239) }\end{array}$ & I & 42 & $\begin{array}{l}0.2-800 \mu \mathrm{g} / \text { day, } 4 \text { weeks infusion }+2 \text { weeks off, for } \\
\text { up to } 5 \text { cycles. Average } 2.5 \pm 2.6 \text { cycles }\end{array}$ & $\begin{array}{l}\text { ORR } 31 \%, \text { sCR } 14 \%, \text { CR } 7 \% \text {, } \\
\text { VGPR } 4.8 \%, \text { PR } 4.8 \%\end{array}$ \\
\hline $\begin{array}{l}\text { BCMA(bivalent)/CD3 } \\
\text { (monovalent) (CC-93269) } \\
\text { (NCT03486067) }\end{array}$ & 1 & 19 & $\begin{array}{l}0.15-10 \mathrm{mg} / \text { day for a } 28 \text {-day cycle (D1, 8, } 15 \text {, and } 22 \\
\text { for Cycles 1-3; D1 and } 15 \text { for Cycles 4-6; and on D1 for } \\
\text { Cycle 7). Median } 4 \text { cycles Median DOT } 14.6 \text { weeks }\end{array}$ & $\begin{array}{l}12 \text { patients } w / \text { dose of } \geq 6 \text { mg; } \\
\text { ORR } 10(83.3 \%) ; \text { sCR/CR } 4 \\
(33.3 \%), \text { VGPR } 7(58.3 \%)\end{array}$ \\
\hline $\begin{array}{l}\text { BCMA/CD3, lgG2a backbone } \\
(\text { PF-06863135) (NCT03269136) }\end{array}$ & I & 17 & $\begin{array}{l}\text { Once weekly non-continuous infusion in } 6 \text { dose- } \\
\text { escalation groups }\end{array}$ & $\begin{array}{l}\text { Minimal response } 1(6 \%) \text {, SD } 6 \\
(35 \%), \text { PD } 9(53 \%)\end{array}$ \\
\hline $\begin{array}{l}\text { BCMA/CD3 (REGN5458) } \\
\text { (NCT03761108) }\end{array}$ & 1 & 7 & $\begin{array}{l}6 \mathrm{mg} / \mathrm{kg}, 16 \text { weekly doses + maintenance } 12 \text { doses } \\
\text { per } 2 \text { weeks }\end{array}$ & ORR $4(53.3 \%)$ \\
\hline
\end{tabular}

PD: Progressive disease; SD: stable disease; mDOR: median duration of response; mPFS: median progression-free survival; ORR: overall response rate; VGPR: very good partial response; CR: complete response; PR: partial response; sCR: stringent complete response; MRD: minimal residual disease.

Table 8. Targeted therapy in multiple myeloma

\begin{tabular}{|c|c|c|c|}
\hline Mutations & Targeted therapy & Mutations & Targeted therapy \\
\hline 1. KRAS mutation & Selumetinib $^{[136]}$ & 5. BRAF mutation & Vemurafenib $^{[130]}$ \\
\hline 2. NRAS mutation & Cobimetinib $^{[137]}$ & $\begin{array}{l}\text { 6. BCL-2 mutation } \\
\text { (t } 11: 14)\end{array}$ & $\begin{array}{l}\text { BCL-2 Inhibitors }{ }^{[138]} \\
\text { - Venetoclax } \\
\text { - Navitoclax }\end{array}$ \\
\hline 3. MYC Translocations & BET inhibitors ${ }^{[139]}$ & $\begin{array}{l}\text { 7. FGFR3 mutation } \\
\text { (t } 4: 14 \text { ) }\end{array}$ & $\begin{array}{l}\text { BGJ398 } \\
\text { AZD4540] } \\
{[141]}\end{array}$ \\
\hline 4. MEK mutation & $\begin{array}{l}\text { MEK inhibitor }{ }^{[142]} \\
\text { - Trametinib } \\
\text { - Cobimetinib }\end{array}$ & $\begin{array}{l}\text { 8. del 1p (CDKN2C), } \\
\text { t 11:14 (CCND1) } \\
\text { t 6:14 (CCND3) }\end{array}$ & Palbociclib ${ }^{[143]}$ \\
\hline
\end{tabular}

inhibitors address another area of therapy development based on mutational landscapes. This would enable powerful therapeutic combinations for high-risk MM patients previously treated with a non-personalized approach. Table 8 includes examples of therapies targeting specific mutations in MM.

\section{CONCLUSION}

Genetic studies in MM patients have revealed mutational landscapes and a clearer understanding of disease pathophysiology and molecular heterogeneity. Hence, instead of a single treatment approach, a series of genetically-targeted treatment combinations based on the genetic subtypes would be effective. However, further studies using single-cell RNA sequencing technology are required on MM patient samples to extend our knowledge of clonal evolution and to precisely identify resistance mechanisms for novel therapeutic target identification. With current drug development, including antibody-drug, MM patients will eventually develop drug resistance. Obviously, there are patients either intrinsic-resistant or acquired-resistant to multiple drug treatments. There are very active drug development and clinical trials ongoing to develop bispecific antibody-drug conjugation to overcome multiple drug resistance, including single antibody-drug 
treatment.

\section{DECLARATIONS}

\section{Authors' contributions}

Review paper writing and editing: Sadaf H, Hong H, Maqbool M, Emhoff K, Lin J, Yan S, Anwer F, Zhao J

\section{Availability of data and materials}

Not applicable.

\section{Financial support and sponsorship}

This work was financially supported by grants from: NCI R00 CA172292, 1R01CA251141 (to Zhao J) and start-up funds (to Zhao J) and two Core Utilization Pilot Grants (to Zhao J) from the Clinical and Translational Science Collaborative of Cleveland, V Foundation Scholar Award, American Society of Hematology (ASH) bridge grant (to Zhao J), National Institutes of Health training grant T32 CA094186, Training in Computational Genomic Epidemiology of Cancer (CoGEC) career development program (to Lin J).

\section{Conflicts of interest}

Jianjun Zhao has a consulting role for Curio Science. Faiz Anwer has a consulting or advisory role for Seattle Genetics, Incyte Corporation Speakers' Bureau, Company: Incyte Corporation; receives travel and accommodations expenses from Seattle Genetics, Incyte; receives honoraria from Incyte, Company: Seattle Genetics; and received research funding from Seattle Genetics, Company: Celgene, Acetylon Pharmaceuticals, Millennium, Astellas Pharma and AbbVie. The authors have no other relevant affiliations or financial involvement with any organization or entity with a financial interest in or financial conflict with the subject matter or materials discussed in the manuscript apart from those disclosed.

\section{Ethical approval and consent to participate}

Not applicable.

\section{Consent for publication}

Not applicable.

\section{Copyright}

(c) The Author(s) 2022.

\section{REFERENCES}

1. Manier S, Salem KZ, Park J, Landau DA, Getz G, Ghobrial IM. Genomic complexity of multiple myeloma and its clinical implications. Nat Rev Clin Oncol 2017;14:100-13. DOI PubMed

2. Talley PJ, Chantry AD, Buckle CH. Genetics in myeloma: genetic technologies and their application to screening approaches in myeloma. Br Med Bull 2015;113:15-30. DOI PubMed

3. Janz S, Zhan F, Sun F, et al. Germline risk contribution to genomic instability in multiple myeloma. Front Genet 2019;10:424. DOI PubMed PMC

4. Liyanage M, Coleman A, du Manoir S, et al. Multicolour spectral karyotyping of mouse chromosomes. Nat Genet 1996;14:312-5. DOI PubMed

5. Grade M, Difilippantonio MJ, Camps J. Patterns of Chromosomal Aberrations in Solid Tumors. Recent Results Cancer Res 2015;200:115-42. DOI PubMed PMC

6. Bahr GF. The fibrous structure of human chromosomes in relation to rearrangements and aberrations; a theoretical consideration. Fed Proc 1975;34:2209-17. PubMed

7. Chapman MA, Lawrence MS, Keats JJ, et al. Initial genome sequencing and analysis of multiple myeloma. Nature 2011;471:467-72. DOI PubMed PMC

8. Raffan E, Semple RK. Next generation sequencing--implications for clinical practice. Br Med Bull 2011;99:53-71. DOI

9. Went M, Kinnersley B, Sud A, et al. Transcriptome-wide association study of multiple myeloma identifies candidate susceptibility genes. Hum Genomics 2019;13:37. DOI PubMed PMC 
10. van Laar R, Flinchum R, Brown N, et al. Translating a gene expression signature for multiple myeloma prognosis into a robust highthroughput assay for clinical use. BMC Med Genomics 2014;7:25. DOI PubMed PMC

11. Samo AA, Li J, Zhou M, et al. MCL1 gene co-expression module stratifies multiple myeloma and predicts response to proteasome inhibitor-based therapy. Genes Chromosomes Cancer 2018;57:420-9. DOI PubMed

12. Kuehl WM, Bergsagel PL. Early genetic events provide the basis for a clinical classification of multiple myeloma. Hematology Am Soc Hematol Educ Program 2005;346-52. DOI PubMed

13. Bergsagel PL, Kuehl WM. Molecular pathogenesis and a consequent classification of multiple myeloma. J Clin Oncol 2005;23:63338. DOI PubMed

14. Prideaux SM, Conway O'Brien E, Chevassut TJ. The genetic architecture of multiple myeloma. Adv Hematol 2014;2014:864058. DOI PubMed PMC

15. Bergsagel PL, Kuehl WM, Zhan F, Sawyer J, Barlogie B, Shaughnessy J Jr. Cyclin D dysregulation: an early and unifying pathogenic event in multiple myeloma. Blood 2005;106:296-303. DOI PubMed PMC

16. Clay-Gilmour AI, Hildebrandt MAT, Brown EE, et al. Coinherited genetics of multiple myeloma and its precursor, monoclonal gammopathy of undetermined significance. Blood Adv 2020;4:2789-97. DOI PubMed PMC

17. Kristinsson SY, Björkholm M, Goldin LR, et al. Patterns of hematologic malignancies and solid tumors among 37,838 first-degree relatives of 13,896 patients with multiple myeloma in Sweden. Int J Cancer 2009;125:2147-50. DOI PubMed PMC

18. Altieri A, Chen B, Bermejo JL, Castro F, Hemminki K. Familial risks and temporal incidence trends of multiple myeloma. Eur J Cancer 2006;42:1661-70. DOI PubMed

19. Vachon CM, Kyle RA, Therneau TM, et al. Increased risk of monoclonal gammopathy in first-degree relatives of patients with multiple myeloma or monoclonal gammopathy of undetermined significance. Blood 2009;114:785-90. DOI PubMed PMC

20. Morgan GJ, Johnson DC, Weinhold N, et al. Inherited genetic susceptibility to multiple myeloma. Leukemia 2014;28:518-24. DOI PubMed

21. Broderick P, Chubb D, Johnson DC, et al. Common variation at 3p22.1 and 7p15.3 influences multiple myeloma risk. Nat Genet 2011;44:58-61. DOI PubMed PMC

22. Koura DT, Langston AA. Inherited predisposition to multiple myeloma. Ther Adv Hematol 2013;4:291-7. DOI PubMed PMC

23. Chubb D, Weinhold N, Broderick P, et al. Common variation at 3q26.2, 6p21.33, 17p11.2 and 22q13.1 influences multiple myeloma risk. Nat Genet 2013;45:1221-5. DOI PubMed PMC

24. Martino A, Campa D, Jamroziak K, et al. Impact of polymorphic variation at 7p15.3, 3p22.1 and 2p23.3 loci on risk of multiple myeloma. Br J Haematol 2012;158:805-9. DOI PubMed

25. Weinhold N, Johnson DC, Rawstron AC, et al. Inherited genetic susceptibility to monoclonal gammopathy of unknown significance. Blood 2014;123:2513-7; quiz 2593. DOI PubMed

26. Ziv E, Dean E, Hu D, et al. Genome-wide association study identifies variants at 16 p13 associated with survival in multiple myeloma patients. Nat Commun 2015;6:7539. DOI PubMed PMC

27. Mitchell JS, Li N, Weinhold N, et al. Genome-wide association study identifies multiple susceptibility loci for multiple myeloma. Nat Commun 2016;7:12050. DOI PubMed PMC

28. Went M, Sud A, Försti A, et al; PRACTICAL consortium. Identification of multiple risk loci and regulatory mechanisms influencing susceptibility to multiple myeloma. Nat Commun 2018;9:3707. DOI PubMed PMC

29. Duran-Lozano L, Thorleifsson G, Lopez de Lapuente Portilla A, et al. Germline variants at SOHLH2 influence multiple myeloma risk. Blood Cancer J 2021;11:76. DOI PubMed PMC

30. Landgren O, Weiss BM. Patterns of monoclonal gammopathy of undetermined significance and multiple myeloma in various ethnic/racial groups: support for genetic factors in pathogenesis. Leukemia 2009;23:1691-7. DOI PubMed

31. Greenberg AJ, Vachon CM, Rajkumar SV. Disparities in the prevalence, pathogenesis and progression of monoclonal gammopathy of undetermined significance and multiple myeloma between blacks and whites. Leukemia 2012;26:609-14. DOI PubMed PMC

32. Costa LJ, Brill IK, Omel J, Godby K, Kumar SK, Brown EE. Recent trends in multiple myeloma incidence and survival by age, race, and ethnicity in the United States. Blood Adv 2017;1:282-7. DOI PubMed PMC

33. Waxman AJ, Mink PJ, Devesa SS, et al. Racial disparities in incidence and outcome in multiple myeloma: a population-based study. Blood 2010;116:5501-6. DOI PubMed PMC

34. Du Z, Weinhold N, Song GC, et al. A meta-analysis of genome-wide association studies of multiple myeloma among men and women of African ancestry. Blood Adv 2020;4:181-90. DOI PubMed PMC

35. Cozen W, Gebregziabher M, Conti DV, et al. Interleukin-6-related genotypes, body mass index, and risk of multiple myeloma and plasmacytoma. Cancer Epidemiol Biomarkers Prev 2006;15:2285-91. DOI PubMed

36. Weinhold N, Meissner T, Johnson DC, et al. The 7p15.3 (rs4487645) association for multiple myeloma shows strong allele-specific regulation of the MYC-interacting gene CDCA7L in malignant plasma cells. Haematologica 2015;100:e110-3. DOI PubMed PMC

37. Li N, Johnson DC, Weinhold N, et al. Multiple myeloma risk variant at 7p15.3 creates an IRF4-binding site and interferes with CDCA7L expression. Nat Commun 2016;7:13656. DOI PubMed PMC

38. Baughn LB, Pearce K, Larson D, et al. Differences in genomic abnormalities among African individuals with monoclonal gammopathies using calculated ancestry. Blood Cancer J 2018;8:96. DOI PubMed PMC

39. Keats JJ, Reiman T, Maxwell CA, et al. In multiple myeloma, $\mathrm{t}(4 ; 14)(\mathrm{p} 16 ; \mathrm{q} 32)$ is an adverse prognostic factor irrespective of FGFR3 expression. Blood 2003;101:1520-9. DOI PubMed

40. Chang H, Sloan S, Li D, et al. The $\mathrm{t}(4 ; 14)$ is associated with poor prognosis in myeloma patients undergoing autologous stem cell transplant. Br J Haematol 2004;125:64-8. DOI PubMed 
41. Santra M, Zhan F, Tian E, Barlogie B, Shaughnessy J Jr. A subset of multiple myeloma harboring the t(4;14)(p16;q32) translocation lacks FGFR3 expression but maintains an IGH/MMSET fusion transcript. Blood 2003;101:2374-6. DOI PubMed

42. Keats JJ, Maxwell CA, Taylor BJ, et al. Overexpression of transcripts originating from the MMSET locus characterizes all $\mathrm{t}(4 ; 14)(\mathrm{p} 16 ; \mathrm{q} 32)$-positive multiple myeloma patients. Blood 2005;105:4060-9. DOI PubMed PMC

43. Cappellen D, De Oliveira C, Ricol D, et al. Frequent activating mutations of FGFR3 in human bladder and cervix carcinomas. Nat Genet 1999;23:18-20. DOI PubMed

44. Pei H, Zhang L, Luo K, et al. MMSET regulates histone H4K20 methylation and 53BP1 accumulation at DNA damage sites. Nature 2011;470:124-8. DOI PubMed PMC

45. Avet-Loiseau H, Leleu X, Roussel M, et al. Bortezomib plus dexamethasone induction improves outcome of patients with $\mathrm{t}(4 ; 14)$ myeloma but not outcome of patients with del(17p). J Clin Oncol 2010;28:4630-4. DOI PubMed

46. Shaughnessy J Jr, Gabrea A, Qi Y, et al. Cyclin D3 at 6p21 is dysregulated by recurrent chromosomal translocations to immunoglobulin loci in multiple myeloma. Blood 2001;98:217-23. DOI PubMed

47. Zhan F, Huang Y, Colla S, et al. The molecular classification of multiple myeloma. Blood 2006;108:2020-8. DOI PubMed PMC

48. Mao X, Cao B, Wood TE, et al. A small-molecule inhibitor of D-cyclin transactivation displays preclinical efficacy in myeloma and leukemia via phosphoinositide 3-kinase pathway. Blood 2011;117:1986-97. DOI PubMed

49. Avet-Loiseau H, Malard F, Campion L, et al; Intergroupe Francophone du Myélome. Translocation t(14;16) and multiple myeloma: is it really an independent prognostic factor? Blood 2011;117:2009-11. DOI PubMed

50. Hurt EM, Wiestner A, Rosenwald A, et al. Overexpression of c-maf is a frequent oncogenic event in multiple myeloma that promotes proliferation and pathological interactions with bone marrow stroma. Cancer Cell 2004;5:191-9. DOI PubMed

51. Walker BA, Wardell CP, Murison A, et al. APOBEC family mutational signatures are associated with poor prognosis translocations in multiple myeloma. Nat Commun 2015;6:6997. DOI PubMed PMC

52. Ross FM, Chiecchio L, Dagrada G, et al; UK Myeloma Forum. The $\mathrm{t}(14 ; 20)$ is a poor prognostic factor in myeloma but is associated with long-term stable disease in monoclonal gammopathies of undetermined significance. Haematologica 2010;95:1221-5. DOI PubMed PMC

53. Solvason N, Wu WW, Kabra N, Wu X, Lees E, Howard MC. Induction of cell cycle regulatory proteins in anti-immunoglobulinstimulated mature B lymphocytes. J Exp Med 1996;184:407-17. DOI PubMed PMC

54. Walker BA, Boyle EM, Wardell CP, et al. Mutational spectrum, copy number changes, and outcome: results of a sequencing study of patients with newly diagnosed myeloma. J Clin Oncol 2015;33:3911-20. DOI PubMed PMC

55. Avet-Loiseau H, Gerson F, Magrangeas F, Minvielle S, Harousseau JL, Bataille R; Intergroupe Francophone du Myélome. Rearrangements of the c-myc oncogene are present in 15\% of primary human multiple myeloma tumors. Blood 2001;98:3082-6. DOI PubMed

56. Dib A, Gabrea A, Glebov OK, Bergsagel PL, Kuehl WM. Characterization of MYC translocations in multiple myeloma cell lines. $J$ Natl Cancer Inst Monogr 2008;(39):25-31. DOI PubMed PMC

57. Walker BA, Leone PE, Chiecchio L, et al. A compendium of myeloma-associated chromosomal copy number abnormalities and their prognostic value. Blood 2010;116:e56-65. DOI PubMed

58. Debes-Marun CS, Dewald GW, Bryant S, et al. Chromosome abnormalities clustering and its implications for pathogenesis and prognosis in myeloma. Leukemia 2003;17:427-36. DOI PubMed

59. Chng WJ, Van Wier SA, Ahmann GJ, et al. A validated FISH trisomy index demonstrates the hyperdiploid and nonhyperdiploid dichotomy in MGUS. Blood 2005;106:2156-61. DOI PubMed PMC

60. Onodera N, Mccabe N, Rubin C. Formation of a hyperdiploid karyotype in childhood acute lymphoblastic leukemia [see comments]. Blood 1992;80:203-8. PubMed

61. Chng WJ, Kumar S, Vanwier S, et al. Molecular dissection of hyperdiploid multiple myeloma by gene expression profiling. Cancer Res 2007;67:2982-9. DOI PubMed

62. Smadja NV, Bastard C, Brigaudeau C, Leroux D, Fruchart C; Groupe Français de Cytogénétique Hématologique. Hypodiploidy is a major prognostic factor in multiple myeloma. Blood 2001;98:2229-38. DOI PubMed

63. Chretien ML, Corre J, Lauwers-Cances V, et al. Understanding the role of hyperdiploidy in myeloma prognosis: which trisomies really matter? Blood 2015;126:2713-9. DOI PubMed PMC

64. Pawlyn C, Melchor L, Murison A, et al. Coexistent hyperdiploidy does not abrogate poor prognosis in myeloma with adverse cytogenetics and may precede IGH translocations. Blood 2015;125:831-40. DOI

65. Sawyer JR, Tian E, Heuck CJ, et al. Jumping translocations of 1q12 in multiple myeloma: a novel mechanism for deletion of $17 \mathrm{p}$ in cytogenetically defined high-risk disease. Blood 2014;123:2504-12. DOI PubMed PMC

66. Schmidt TM, Barwick BG, Joseph N, et al. Gain of Chromosome 1q is associated with early progression in multiple myeloma patients treated with lenalidomide, bortezomib, and dexamethasone. Blood Cancer J 2019;9:94. DOI PubMed PMC

67. Li C, Wendlandt EB, Darbro B, et al. Genetic Analysis of multiple myeloma identifies cytogenetic alterations implicated in disease complexity and progression. Cancers (Basel) 2021;13:517. DOI PubMed PMC

68. Boyd KD, Ross FM, Walker BA, et al; NCRI Haematology Oncology Studies Group. Mapping of chromosome 1p deletions in myeloma identifies FAM46C at $1 \mathrm{p} 12$ and $\mathrm{CDKN} 2 \mathrm{C}$ at $1 \mathrm{p} 32.3$ as being genes in regions associated with adverse survival. Clin Cancer Res 2011;17:7776-84. DOI PubMed PMC

69. Fonseca R, Bergsagel PL, Drach J, et al; International Myeloma Working Group. International Myeloma Working Group molecular classification of multiple myeloma: spotlight review. Leukemia 2009;23:2210-21. DOI PubMed PMC

70. Tricot G, Barlogie B, Jagannath S, et al. Poor prognosis in multiple myeloma is associated only with partial or complete deletions of 
chromosome 13 or abnormalities involving 11q and not with other karyotype abnormalities. Blood 1995;86:4250-6. PubMed

71. Lodé L, Eveillard M, Trichet V, et al. Mutations in TP53 are exclusively associated with del(17p) in multiple myeloma. Haematologica 2010;95:1973-6. DOI PubMed PMC

72. Drach J, Ackermann J, Fritz E, et al. Presence of a p53 gene deletion in patients with multiple myeloma predicts for short survival after conventional-dose chemotherapy. Blood 1998;92:802-9. PubMed

73. Avet-Loiseau H, Attal M, Moreau P, et al. Genetic abnormalities and survival in multiple myeloma: the experience of the Intergroupe Francophone du Myélome. Blood 2007;109:3489-95. DOI PubMed

74. Gmidène A, Saad A, Avet-Loiseau H. 8p21.3 deletion suggesting a probable role of TRAIL-R1 and TRAIL-R2 as candidate tumor suppressor genes in the pathogenesis of multiple myeloma. Med Oncol 2013;30:489. DOI PubMed

75. Pratt G. Molecular aspects of multiple myeloma. Mol Pathol 2002;55:273-83. DOI PubMed PMC

76. Oeckinghaus A, Ghosh S. The NF-kappaB family of transcription factors and its regulation. Cold Spring Harb Perspect Biol 2009;1:a000034. DOI PubMed PMC

77. Annunziata CM, Davis RE, Demchenko Y, et al. Frequent engagement of the classical and alternative NF-kappaB pathways by diverse genetic abnormalities in multiple myeloma. Cancer Cell 2007;12:115-30. DOI PubMed PMC

78. Keats JJ, Fonseca R, Chesi M, et al. Promiscuous mutations activate the noncanonical NF-kappaB pathway in multiple myeloma. Cancer Cell 2007;12:131-44. DOI PubMed PMC

79. Zhang W, Liu HT. MAPK signal pathways in the regulation of cell proliferation in mammalian cells. Cell Res 2002;12:9-18. DOI PubMed

80. Chng WJ, Gonzalez-Paz N, Price-Troska T, et al. Clinical and biological significance of RAS mutations in multiple myeloma. Leukemia 2008;22:2280-4. DOI PubMed PMC

81. Patrawala S, Puzanov I. Vemurafenib (RG67204, PLX4032): a potent, selective BRAF kinase inhibitor. Future Oncol 2012;8:509-23. DOI PubMed

82. Bharti AC, Shishodia S, Reuben JM, et al. Nuclear factor-kappaB and STAT3 are constitutively active in CD138+ cells derived from multiple myeloma patients, and suppression of these transcription factors leads to apoptosis. Blood 2004;103:3175-84. DOI PubMed

83. Kawano M, Hirano T, Matsuda T, et al. Autocrine generation and requirement of BSF-2/IL-6 for human multiple myelomas. Nature 1988;332:83-5. DOI PubMed

84. De Vos J, Jourdan M, Tarte K, Jasmin C, Klein B. JAK2 tyrosine kinase inhibitor tyrphostin AG490 downregulates the mitogenactivated protein kinase (MAPK) and signal transducer and activator of transcription (STAT) pathways and induces apoptosis in myeloma cells. Br J Haematol 2000;109:823-8. DOI PubMed

85. Alas S, Bonavida B. Inhibition of constitutive STAT3 activity sensitizes resistant non-Hodgkin's lymphoma and multiple myeloma to chemotherapeutic drug-mediated apoptosis. Clin Cancer Res 2003;9:316-26. PubMed

86. Osaki M, Oshimura M, Ito H. PI3K-Akt pathway: its functions and alterations in human cancer. Apoptosis 2004;9:667-76. DOI PubMed

87. Aronson LI, Davenport EL, Giuntoli SG, et al. Autophagy is a key myeloma survival pathway that can be manipulated therapeutically to enhance apoptosis. Blood 2010;116:4083. DOI

88. Tasaka T, Berenson J, Vescio R, et al. Analysis of the p16INK4A, p15INK4B and p18INK4C genes in multiple myeloma. $\mathrm{Br} J$ Haematol 1997;96:98-102. DOI PubMed

89. Uchida T, Kinoshita T, Ohno T, Ohashi H, Nagai H, Saito H. Hypermethylation of p16INK4A gene promoter during the progression of plasma cell dyscrasia. Leukemia 2001;15:157-65. DOI PubMed

90. Kassambara A, Gourzones-Dmitriev C, Sahota S, et al. A DNA repair pathway score predicts survival in human multiple myeloma: the potential for therapeutic strategy. Oncotarget 2014;5:2487-98. DOI PubMed PMC

91. Neri P, Ren L, Gratton K, et al. Bortezomib-induced "BRCAness" sensitizes multiple myeloma cells to PARP inhibitors. Blood 2011;118:6368-79. DOI PubMed PMC

92. Hu Y, Lin J, Fang H, et al. Targeting the MALAT1/PARP1/LIG3 complex induces DNA damage and apoptosis in multiple myeloma. Leukemia 2018;32:2250-62. DOI PubMed PMC

93. Perrot A, Lauwers-Cances V, Corre J, et al. Minimal residual disease negativity using deep sequencing is a major prognostic factor in multiple myeloma. Blood 2018;132:2456-64. DOI PubMed PMC

94. Marchesini M, Fiorini E, Colla S. RNA processing: a new player of genomic instability in multiple myeloma. Oncoscience 2017;4:73-4. DOI PubMed PMC

95. Fucci C, Resnati M, Riva E, et al. The interaction of the tumor suppressor FAM46C with $\mathrm{p} 62$ and FNDC3 proteins integrates protein and secretory homeostasis. Cell Rep 2020;32:108162. DOI PubMed

96. Colla S, Ong DS, Ogoti Y, et al. Telomere dysfunction drives aberrant hematopoietic differentiation and myelodysplastic syndrome. Cancer Cell 2015;27:644-57. DOI PubMed PMC

97. Pereira B, Billaud M, Almeida R. RNA-binding proteins in cancer: old players and new actors. Trends Cancer 2017;3:506-28. DOI PubMed

98. Marchesini M, Ogoti Y, Fiorini E, et al. ILF2 is a regulator of RNA splicing and DNA damage response in 1q21-amplified multiple myeloma. Cancer Cell 2017;32:88-100.e6. DOI PubMed PMC

99. Shaffer AL, Emre NC, Lamy L, et al. IRF4 addiction in multiple myeloma. Nature 2008;454:226-31. DOI PubMed PMC

100. Greenberg AJ, Walters DK, Kumar SK, Rajkumar SV, Jelinek DF. Responsiveness of cytogenetically discrete human myeloma cell lines to lenalidomide: lack of correlation with cereblon and interferon regulatory factor 4 expression levels. Eur J Haematol 2013;91:504-13. DOI PubMed PMC 
101. Schuster SR, Kortuem KM, Zhu YX, et al. The clinical significance of cereblon expression in multiple myeloma. Leuk Res 2014;38:23-8. DOI PubMed PMC

102. Mandelbaum J, Bhagat G, Tang H, et al. BLIMP1 is a tumor suppressor gene frequently disrupted in activated B cell-like diffuse large B cell lymphoma. Cancer Cell 2010;18:568-79. DOI PubMed PMC

103. Esteve FR, Roodman GD. Pathophysiology of myeloma bone disease. Best Pract Res Clin Haematol 2007;20:613-24. DOI PubMed

104. Tian E, Zhan F, Walker R, et al. The role of the Wnt-signaling antagonist DKK1 in the development of osteolytic lesions in multiple myeloma. N Engl J Med 2003;349:2483-94. DOI PubMed

105. Qiang YW, Chen Y, Stephens O, et al. Myeloma-derived Dickkopf-1 disrupts Wnt-regulated osteoprotegerin and RANKL production by osteoblasts: a potential mechanism underlying osteolytic bone lesions in multiple myeloma. Blood 2008;112:196-207. DOI PubMed PMC

106. Fulciniti M, Tassone P, Hideshima T, et al. Anti-DKK1 mAb (BHQ880) as a potential therapeutic agent for multiple myeloma. Blood 2009;114:371-9. DOI PubMed PMC

107. Cea M, Cagnetta A, Adamia S, et al. Evidence for a role of the histone deacetylase SIRT6 in DNA damage response of multiple myeloma cells. Blood 2016;127:1138-50. DOI PubMed PMC

108. Song Y, Li S, Ray A, et al. Blockade of deubiquitylating enzyme Rpn11 triggers apoptosis in multiple myeloma cells and overcomes bortezomib resistance. Oncogene 2017;36:5631-8. DOI PubMed PMC

109. Qin Y, Zhang S, Deng S, et al. Epigenetic silencing of miR-137 induces drug resistance and chromosomal instability by targeting AURKA in multiple myeloma. Leukemia 2017;31:1123-35. DOI PubMed

110. Caracciolo D, Di Martino MT, Amodio N, et al. miR-22 suppresses DNA ligase III addiction in multiple myeloma. Leukemia 2019;33:487-98. DOI PubMed PMC

111. Walker BA, Wardell CP, Chiecchio L, et al. Aberrant global methylation patterns affect the molecular pathogenesis and prognosis of multiple myeloma. Blood 2011;117:553-62. DOI PubMed

112. Tricot G. New insights into role of microenvironment in multiple myeloma. Lancet 2000;355:248-50. DOI PubMed

113. Klein B, Zhang X, Lu Z, Bataille R. Interleukin-6 in human multiple myeloma. Blood 1995;85:863-72. PubMed

114. Zhan F, Hardin J, Kordsmeier B, et al. Global gene expression profiling of multiple myeloma, monoclonal gammopathy of undetermined significance, and normal bone marrow plasma cells. Blood 2002;99:1745-57. DOI PubMed

115. Hazlehurst LA, Damiano JS, Buyuksal I, Pledger WJ, Dalton WS. Adhesion to fibronectin via beta1 integrins regulates p27kip1 levels and contributes to cell adhesion mediated drug resistance (CAM-DR). Oncogene 2000;19:4319-27. DOI PubMed

116. Mohty M, Harousseau JL. Treatment of autologous stem cell transplant-eligible multiple myeloma patients: ten questions and answers. Haematologica 2014;99:408-16. DOI PubMed PMC

117. Hideshima T, Raje N, Richardson PG, Anderson KC. A review of lenalidomide in combination with dexamethasone for the treatment of multiple myeloma. Ther Clin Risk Manag 2008;4:129-36. DOI PubMed PMC

118. Weber DM, Chen C, Niesvizky R, et al; Multiple Myeloma (009) Study Investigators. Lenalidomide plus dexamethasone for relapsed multiple myeloma in North America. N Engl J Med 2007;357:2133-42. DOI PubMed

119. Abramson HN. Monoclonal antibodies for the treatment of multiple myeloma: an update. Int J Mol Sci 2018;19:3924. DOI PubMed PMC

120. Ito S. Proteasome inhibitors for the treatment of multiple myeloma. Cancers (Basel) 2020;12:265. DOI PubMed PMC

121. Mikhael J. Treatment options for triple-class refractory multiple myeloma. Clin Lymphoma Myeloma Leuk 2020;20:1-7. DOI PubMed

122. Gandhi UH, Cornell RF, Lakshman A, et al. Outcomes of patients with multiple myeloma refractory to CD38-targeted monoclonal antibody therapy. Leukemia 2019;33:2266-75. DOI PubMed PMC

123. Gerrie AS, Mikhael JR, Cheng L, et al. D(T)PACE as salvage therapy for aggressive or refractory multiple myeloma. Br J Haematol 2013;161:802-10. DOI PubMed

124. Griffin PT, Ho VQ, Fulp W, et al. A comparison of salvage infusional chemotherapy regimens for recurrent/refractory multiple myeloma. Cancer 2015;121:3622-30. DOI PubMed

125. Michael M, Bruns I, Bölke E, et al. Bendamustine in patients with relapsed or refractory multiple myeloma. Eur J Med Res 2010;15:13-9. DOI PubMed PMC

126. Lau IJ, Smith D, Aitchison R, et al. Bendamustine in combination with thalidomide and dexamethasone is a viable salvage option in myeloma relapsed and/or refractory to bortezomib and lenalidomide. Ann Hematol 2015;94:643-9. DOI PubMed

127. Ludwig H, Kasparu H, Leitgeb C, et al. Bendamustine-bortezomib-dexamethasone is an active and well-tolerated regimen in patients with relapsed or refractory multiple myeloma. Blood 2014;123:985-91. DOI PubMed PMC

128. San-miguel JF, Hungria VTM, Yoon S, et al. Panobinostat plus bortezomib and dexamethasone versus placebo plus bortezomib and dexamethasone in patients with relapsed or relapsed and refractory multiple myeloma: a multicentre, randomised, double-blind phase 3 trial. Lancet Oncol 2014;15:1195-206. DOI PubMed

129. Richardson PG, Schlossman RL, Alsina M, et al. PANORAMA 2: panobinostat in combination with bortezomib and dexamethasone in patients with relapsed and bortezomib-refractory myeloma. Blood 2013;122:2331-7. DOI PubMed

130. Siegel DS, Dimopoulos M, Jagannath S, et al. VANTAGE 095: an international, multicenter, open-label study of vorinostat (MK0683) in combination with bortezomib in patients with relapsed and refractory multiple myeloma. Clin Lymphoma Myeloma Leuk 2016;16:329-34.e1. DOI PubMed

131. Dimopoulos M, Siegel DS, Lonial S, et al. Vorinostat or placebo in combination with bortezomib in patients with multiple myeloma (VANTAGE 088): a multicentre, randomised, double-blind study. Lancet Oncol 2013;14:1129-40. DOI PubMed 
132. Attal M, Lauwers-Cances V, Hulin C, et al; IFM 2009 Study. Lenalidomide, bortezomib, and dexamethasone with transplantation for myeloma. N Engl J Med 2017;376:1311-20. DOI PubMed PMC

133. Richter J, Madduri D, Richard S, Chari A. Selinexor in relapsed/refractory multiple myeloma. Ther Adv Hematol 2020;11:2040620720930629. DOI PubMed PMC

134. Lin Q, Zhao J, Song Y, Liu D. Recent updates on CAR T clinical trials for multiple myeloma. Mol Cancer 2019;18:154. DOI PubMed PMC

135. Yu B, Jiang T, Liu D. BCMA-targeted immunotherapy for multiple myeloma. J Hematol Oncol 2020;13:125. DOI PubMed PMC

136. Jänne PA, Shaw AT, Pereira JR, et al. Selumetinib plus docetaxel for KRAS-mutant advanced non-small-cell lung cancer: a randomised, multicentre, placebo-controlled, phase 2 study. Lancet Oncol 2013;14:38-47. DOI PubMed

137. Abdel-Wahab O, Klimek VM, Gaskell AA, et al. Efficacy of intermittent combined RAF and MEK inhibition in a patient with concurrent BRAF- and NRAS-mutant malignancies. Cancer Discov 2014;4:538-45. DOI PubMed PMC

138. Punnoose EA, Leverson JD, Peale F, et al. Expression profile of BCL-2, BCL-XL, and MCL-1 predicts pharmacological response to the BCL-2 selective antagonist venetoclax in multiple myeloma models. Mol Cancer Ther 2016;15:1132-44. DOI PubMed

139. Filippakopoulos P, Qi J, Picaud S, et al. Selective inhibition of BET bromodomains. Nature 2010;468:1067-73. DOI PubMed PMC

140. Guagnano V, Kauffmann A, Wöhrle S, et al. FGFR genetic alterations predict for sensitivity to NVP-BGJ398, a selective pan-FGFR inhibitor. Cancer Discov 2012;2:1118-33. DOI PubMed

141. Gavine PR, Mooney L, Kilgour E, et al. AZD4547: an orally bioavailable, potent, and selective inhibitor of the fibroblast growth factor receptor tyrosine kinase family. Cancer Res 2012;72:2045-56. DOI PubMed

142. Pawlyn C, Davies FE. Toward personalized treatment in multiple myeloma based on molecular characteristics. Blood 2019;133:66075. DOI PubMed PMC

143. Baughn LB, Di Liberto M, Wu K, et al. A novel orally active small molecule potently induces G1 arrest in primary myeloma cells and prevents tumor growth by specific inhibition of cyclin-dependent kinase 4/6. Cancer Res 2006;66:7661-7. DOI PubMed

144. Jelinek T, Paiva B, Hajek R. Update on PD-1/PD-L1 inhibitors in multiple myeloma. Front Immunol 2018;9:2431. DOI PubMed PMC 